\title{
Consistency of ground-motion predictions from the past four decades: Peak ground velocity and displacement, Arias intensity and relative significant duration
}

\author{
John Douglas
}

Received: date / Accepted: date

\begin{abstract}
Due to the limited observational datasets available for the derivation of groundmotion prediction equations (GMPEs) there is always epistemic uncertainty in the estimated median ground motion. Since the quality and quantity of strong-motion datasets is constantly increasing it would be expected that the epistemic uncertainty in ground-motion prediction (related to lack of knowledge and data) is decreasing. This article is a continuation of the study of Douglas (2010) for ground-motion parameters other than peak ground acceleration (PGA) and elastic response spectral acceleration (SA). The epistemic uncertainty in the prediction of peak ground velocity and displacement, Arias intensity and relative significant duration is investigated by plotting predictions from dozens of GMPEs for these parameters against date of publication for three scenarios. In agreement with the previous study, all ground-motion parameters considered show high epistemic uncertainty (often even higher than previously reported for PGA and SA), suggesting that research efforts for the development of GMPEs for these parameters should continue and that it is vital that this uncertainty is accounted for in seismic hazard assessments. The epistemic uncertainty in the prediction of relative significant duration, however, appears to be much lower than any other strong-motion parameter, which suggests that currently available GMPEs for this intensity measure are sufficiently mature.
\end{abstract}

J. Douglas

RIS/RSI, BRGM, 3 avenue Claude-Guillemin, BP 36009, 45060 Orléans Cedex 2, France

Earthquake Engineering Research Centre, University of Iceland, Austurvegur 2A,

800 Selfoss, Iceland. 
Keywords Strong-motion data $\cdot$ Ground-motion prediction equations (GMPEs) - Epistemic uncertainty $\cdot$ Peak ground velocity $\cdot$ Peak ground displacement $\cdot$ Arias intensity $\cdot$ Relative significant duration

\section{Introduction}

The consistency in predicted peak ground acceleration (PGA) and elastic response spectral acceleration (SA) for 5\% damping and a natural period of $1 \mathrm{~s}$ was discussed in Douglas (2010). In that article, predicted PGAs and SAs from hundreds of published ground-motion prediction equations (GMPEs) for various earthquake scenarios $\left(M_{w} 6\right.$ at $20 \mathrm{~km}$, roughly the best-represented scenario in global strong-motion datasets, and $M_{w} 7.5$ at $10 \mathrm{~km}$ and $M_{w} 5$ at $10 \mathrm{~km}$, at the edges of most databases used to derive GMPEs) were plotted against their publication dates. The purpose of these plots was to investigate the epistemic uncertainty associated with GMPEs and to test whether this uncertainty is decreasing, which would be expected given the accumulation of new data and knowledge and improvements in regression techniques, for example. The scatter in predictions shown on such plots is a rough measure of epistemic uncertainty because, in the absence of such uncertainty, predictions of the median ground motion for a certain scenario should tend to a single value. The plots of Douglas (2010) showed that even though epistemic uncertainty seems to be reducing slightly (predictions from different models are slowly converging), there is still considerable uncertainty in estimated PGAs and SAs even for scenarios that are well represented in strong-motion databanks, and much higher uncertainties for poorly-sampled scenarios (specifically large earthquakes at short distances).

The purpose of this short article is to extend the analysis of Douglas (2010) to strongmotion parameters other than PGA and SA, which are useful for some aspects of engineering seismology and earthquake engineering. The four non-PGA/SA strong-motion parameters with most associated GMPEs are considered here, namely: peak ground velocity (PGV), peak ground displacement (PGD), Arias intensity (AI) (Arias, 1970) and relative significant duration (RSD) (Trifunac and Brady, 1975b). In contrast to PGA and SA, there are far fewer GMPEs published for these parameters but there are still sufficient to enable some conclusions on their predictability to be drawn. Unlike for PGA and SA, my search for GMPEs for the prediction of these other parameters only started recently and hence it is more likely that the collection of non-PGA/SA models considered here are less complete than given 
in Douglas (2011) for PGA and SA. However, a thorough literature search was conducted and various reviews were studied (e.g. Bommer and Martínez-Pereira, 1999; Bommer and Alarcón, 2006; Travasarou et al, 2003; Tromans, 2004). Therefore, it is unlikely that many models are missing. Table 1 lists the considered GMPEs and gives, when possible (some of the original references could not be consulted and some authors do not provide the necessary information), their main characteristics.

In the next section, graphs are presented for the four considered strong-motion parameters and the same three earthquake scenarios as in Douglas (2010). To facilitate comparisons with the results of Douglas (2010) the same scenarios are considered here except that separate plots are not made for broad geographical or tectonic regions [western North America; Europe, the Mediterranean and the Middle East; stable continental regions; and Japan (subduction zones)]. The dependence of PGV, PGD, AI and RSD on tectonic regime is less well studied than for PGA and SA because the vast majority of GMPEs for these parameters are derived for shallow crustal earthquakes in active regions (see Table 1). It is likely that this lack of consideration of tectonic regime will slightly increase the scatter in the following plots. The same graph format is used to facilitate comparisons with the previous graphs for PGA and SA. For example, the ratio of the upper and lower limits of the abscissa, displaying the strong-motion parameter, is 25 and a logarithmic axis is used. As before those studies that were published in peer-reviewed international journals and give basic details of the datasets used for their derivation [criteria 2 and 3 of (Cotton et al, 2006)] and which are not being extrapolated far outside their magnitude-distance range of applicability are indicated. Because this study makes the same choices and considers the same scenarios as Douglas (2010), only brief details are given here. The interested reader is referred to the previous article for more information.

The differences between the aleatory variabilities (sigma) associated with GMPEs for the different parameters are not discussed here. Table IV of Travasarou et al (2003) presents such a comparison for PGA, SA(0.5 s), AI and RSD predicted by a family of GMPEs derived using a similar database, functional form and regression technique. This table shows that the aleatory variabilities for each of these parameters are similar, except for the GMPE for AI, which has a much higher sigma suggesting that $\mathrm{AI}$ is more intrinsically variable. 


\section{Comparing ground-motion predictions}

Models have been adjusted to, where possible: moment magnitude $\left(M_{w}\right)$, distance to the surface projection of the rupture (Joyner-Boore distance) $\left(r_{j b}\right)$, vertical-dipping strike-slip faulting and the geometric mean of the two horizontal components. These adjustments were made using the approaches of Bommer et al (2005) using: for PGV and PGD, style-offaulting and component definition factors of Campbell and Bozorgnia (2007) and for AI, style-of-faulting and component definition factors of Stafford et al (2009) ${ }^{1}$. For the conversion to $M_{w}$ from surface-wave magnitude $\left(M_{S}\right)$ the equation of Ambraseys and Free (1997) was used. Local magnitude $\left(M_{L}\right)$, and other magnitude scales, were assumed equal to $M_{w}$. Harmonization of models is not always possible due to a lack of information in many of the original references on, for example, definition of horizontal component and magnitude scale. This means that the predictions could be in error by roughly $20 \%$ but this will not alter the overall trends, which are the focus of this article (the reader should not seek to over-interpret details in the graphs). The size of the rupture plane and other additional parameters needed to evaluate some of the models have been computed using the methods given in Chapter 7 of Campbell and Bozorgnia (2007). To compute the epicentral and hypocentral distances the hypocentre is assumed to be at one end of the fault at a depth of $10 \mathrm{~km}$ and the site half way along the fault. Some authors seek to model epistemic uncertainty in ground-motion prediction by proposing more than one set of GMPEs, e.g. by providing coefficients for different functional forms (e.g. Stafford et al, 2009). Predictions from each of these variant GMPEs are included here.

Because it is roughly the best-represented scenario in global strong-motion datasets the first scenario considered is a $M_{w} 6$ strike-slip earthquake at $r_{j b}=20 \mathrm{~km}$ on a site classified as NEHRP class C (Eurocode 8 class B) $\left(V_{s, 30}=490 \mathrm{~m} / \mathrm{s}\right)$. If epistemic uncertainty in the prediction of ground motion is decreasing then it should be visible for this scenario since it is where available observations are most abundant and hence GMPEs should be the best constrained. The other two scenarios considered are: $M_{w} 7.5$ strike-slip earthquake at $r_{j b}=$ $10 \mathrm{~km}$, for which there are still few available data, and $M_{w} 5$ strike-slip earthquake at $r_{j b}=$ $10 \mathrm{~km}$, which is at the lower edge of most datasets used for the derivation of GMPEs, for

\footnotetext{
1 Kempton and Stewart (2006) and Bommer et al (2009) find that style-of-faulting does not have a statistically significant effect on RSD. Factors to convert between different component definitions of RSD are not available so no adjustment was attempted.
} 
the same site conditions. It is expected that epistemic uncertainty (and hence scatter in the predictions) will be higher for these two scenarios compared to $M_{w} 6$ at $r_{j b}=20 \mathrm{~km}$ due to the lack of observations and uncertainty over near-source magnitude-scaling, for example. The following sections present the results for the four parameters in turn. As a measure of the dispersion in the median predictions the standard deviation of the common (base 10) logarithm of median estimates for each five-year interval are computed, although because of the limited number of GMPEs this statistic is quite unstable.

As for the analysis shown in Douglas (2010) the median ground motion for the considered scenario obtained from a large (over 13,000 records from over 2,500 events) strongmotion database [the data from the Internet Site for European Strong-motion Data (ISESD) (Ambraseys et al, 2004) with the addition of many accelerograms from western North America and elsewhere] is plotted at all dates. The median should track the predictions, since similar databases were used to derive the GMPEs published up to that date, and the variability in the median should also show a reduction, since more data are being used to compute the averages. The variabilities of the medians are computed here by dividing the standard deviation by $\sqrt{n}$, where $n$ is the number of records used to compute the standard deviation. The medians and their variabilities were computed by considering the available records within $0.5-M_{w}$ units and $10 \mathrm{~km}$ of the scenario of interest and excluding a consideration of local site conditions and style of faulting. It could be argued that these bins are too broad and that a consideration of local site effects should have been made. However, given the limited data available, particularly for $M_{w}>7$, narrow bins would lead to statistics based on few records from only a handful of earthquakes. The median ground motions computed from averaging data within broad bins should not be strongly affected by the width of the bins but the variabilities of these medians may be slightly overestimated. The uniform filtering applied to the strong-motion databank used here (bandpass filtering with cut-offs of 0.25 and $25 \mathrm{~Hz}$ ) means that the PGV and, especially, PGD observations obtained from this databank are likely to be incorrect. The averages of these PGV and PGD observations, however, are added for completeness. AI and RSD from these records, however, are likely to be little affected by the uniform filtering. 
2.1 Peak ground velocity

Because of its various uses in earthquake engineering (Bommer and Alarcón, 2006) and its simplicity, following PGA and SA, PGV is the best served by GMPEs and 96 models were identified and programmed, many of which also provide coefficients for the prediction of PGA and SA. The predicted PGVs and median PGVs from the strong-motion databank for the three considered scenarios are shown in Figure 1 (some predicted PGVs are off the top or bottom of these figures, often because the GMPEs are being extrapolated far outside their range of applicability). These figures show that the dispersion in predicted PGVs from different GMPEs is large (the ratio between the smallest and largest predictions is greater than ten) and that this scatter is not obviously reducing with time (even when considering only models passing basic quality-control criteria), particularly near to large earthquakes. The standard deviation of the common logarithm of median estimates for each five-year interval are around 0.2 for $M_{w} 6$ at $r_{j b}=20 \mathrm{~km}$ and $M_{w} 5$ at $r_{j b}=10 \mathrm{~km}$ and around 0.3 for $M_{w} 7.5$ at $r_{j b}=10 \mathrm{~km}$. Also roughly constant are the average PGV predicted by the models over time. The median observed PGVs are similar to those predicted by the GMPEs although lower for the $M_{w} 7.5$ scenario. A similar conclusion was also noted by Douglas (2010) for PGA and SA(1 s) for large earthquakes, which was related to a number of recent large earthquakes (e.g. Chi-Chi 1999; Kocaeli 1999; Denali 2002) showing lower than expected ground motions (e.g. Ellsworth et al, 2004).

[Fig. 1 about here.]

\subsection{Peak ground displacement}

Because of the difficulty in obtaining reliable PGDs from analogue (and even digital) accelerograms and the limited use of PGD in earthquake engineering, there are only 19 published GMPEs for PGD, which are typically associated with GMPEs for PGV. Although of limited use in most fields of earthquake engineering, the robust prediction of PGD would help constrain the long-period $(>2 \mathrm{~s}$ ) response spectral displacements because these must converge to PGD at very long periods (Faccioli et al, 2004). The predictions from the GMPEs for the three considered scenarios are shown in Figure 2. These graphs show the large dispersion in predictions of PGD, especially near to large earthquakes. This dispersion is probably due in large part to the difficulty in recovering reliable displacement traces from 
strong-motion records because of their high sensitivity to processing (e.g. low-cut filtering) (e.g. Paolucci et al, 2008). The observed PGDs match the predictions reasonably well for the smaller magnitudes but they are considerably lower for the $M_{w} 7.5$ earthquake, which is probably since the application of a low-cut filter with a corner frequency of $0.25 \mathrm{~Hz}$ is likely to lead to significant loss of the true long-period energy from such large events.

[Fig. 2 about here.]

\subsection{Arias intensity}

As noted by, for example, Travasarou et al (2003), AI has a number of uses in earthquake engineering, particularly for slope stability analysis and liquefaction assessment. These uses have motived the development of, at least, 33 GMPEs, including variants, for AI. Some of these GMPEs only give the value of the integral and not the complete expression for AI; for these the constant $\pi / 2 \mathrm{~g}$ was included when plotted. The predictions from these 33 models and the median observed AI for the three scenarios are plotted in Figure 3. The standard deviations of the median predicted AIs are around 0.4 for $M_{w} 5$ at $r_{j b}=10 \mathrm{~km}$, around 0.3 for $M_{w} 6$ at $r_{j b}=20 \mathrm{~km}$ and around 0.2 for $M_{w} 7.5$ at $r_{j b}=10 \mathrm{~km}$. This implies that the epistemic uncertainty in the prediction of median AI for larger earthquakes is lower than that for smaller events, which is counterintuitive since there are far fewer available records for this scenario. Two possible reasons for this observation are that regional differences in AI, modelled within local GMPEs, are stronger for smaller events, and that current GMPE developers for AI have concentrated their efforts on the prediction of AI from large earthquakes. AI was not considered by the NGA developers (Power et al, 2008) and, therefore, there is perhaps a requirement to develop a new generation of models for the prediction of this parameter; there have been some recent attempts in this direction (e.g. Foulser-Piggott and Stafford, 2012).

[Fig. 3 about here.]

\subsection{Relative significant duration}

As noted by Bommer and Martínez-Pereira (1999), many dozens of definitions of strongmotion duration have been proposed, which give widely ranging values. The definition of 
duration that is most commonly used in earthquake engineering (and consequently for which there are most GMPEs available) is the relative significant duration originally defined by Trifunac and Brady (1975b) as the interval between 5 and 95\% of the total Arias intensity. Despite its various uses (e.g. Kempton and Stewart, 2006), e.g. in liquefaction evaluation, only 15 GMPEs have been identified in the literature for the prediction of this parameter. Figure 4 present the history of the predictions from these 15 models and the median observed RSDs for the three scenarios. The epistemic uncertainty in the prediction of median RSD is much lower than for the other ground-motion parameters considered here (the standard deviation of the median predicted RSDs in the past five year is less than 0.1 even for large earthquakes). This suggests that, either: a) epistemic uncertainty in the prediction of this parameter is being under represented by the different models (because they often use similar databases and functional forms) or b) this parameter is easier to predict than the other intensity measures. The widths of the confidence limits for the median observed RSD are narrower than the confidence limits for PGV, PGD and AI [and those for PGA and SA(1s) shown in Douglas (2010)], which hints that the epistemic uncertainty in the prediction of RSD is truly lower than for these other parameters. This could be because the physics underlying the relative duration characteristics of earthquake shaking (e.g. rupture time and wave dispersion and scattering) are perhaps easier to capture in a simple functional form compared with the physics explaining strong-motion amplitudes, measured by the other parameters.

[Fig. 4 about here.]

\section{Conclusions}

There have been recent studies (e.g. Baker, 2007) applying vector-valued probabilistic seismic hazard assessment (VPSHA) (Bazzurro and Cornell, 2002) for the joint prediction of pairs of parameters other than PGA and SA. Recently, Gehl et al (2011) present a method for the derivation of structural fragility functions of more than one intensity measure, which could be coupled with VPSHA for vector-valued risk evaluation. For this type of study the relative uncertainties in the prediction of each parameter are important. This article suggests that the epistemic uncertainties in the prediction of PGV, PGD and AI are higher even than those evidenced by Douglas (2010) for PGA and SA. For PGV and AI, this larger uncertainty is probably principally due to lesser research effort having been made in the development 
of GMPEs for such parameters compared to PGA and SA. Although both parameters have recently been the subject of various articles, e.g. the NGA developers also developed models for the prediction of PGV. The instability in PGD predictions is due to both lack of research interest in the development of GMPEs for this parameter, because of limited engineering applications, but also because PGD is inherently difficult to recover from strong-motion records due to its sensitivity to low-cut filtering (e.g. Boore and Atkinson, 2008). The epistemic uncertainty in the prediction of RSD, on the other hand, seems to be lower than that associated with the prediction of any of the other parameters, which could encourage more consideration of this parameter within earthquake hazard and risk assessments for which it has various engineering applications.

Acknowledgements The work presented in this article has been mainly undertaken within the PERPETUATE (Performance-based approach to earthquake protection of cultural heritage in European and Mediterranean countries) project of the EC-Research Framework Programme FP7 and the internal BRGM research project SEISMORISK. I thank two anonymous reviewers for their constructive comments on a previous version of this article.

\section{References}

Abrahamson N, Silva W (2008) Summary of the Abrahamson \& Silva NGA ground-motion relations. Earthquake Spectra 24(1):67-97, DOI 10.1193/1.2924360

Abrahamson N, Silva W (2009) Errata for "Summary of the Abrahamson and Silva NGA ground-motion relations" by Abrahamson, N. A. and W. J. Silva. Published on PEER NGA website

Abrahamson NA, Shedlock KM (1997) Overview. Seismological Research Letters 68(1):9_ 23

Abrahamson NA, Silva WJ (1996) Empirical ground motion models. Tech. rep., report to Brookhaven National Laboratory. Cited in Stewart et al (2001).

Abrahamson NA, Youngs RR (1992) A stable algorithm for regression analyses using the random effects model. Bulletin of the Seismological Society of America 82(1):505-510

Akkar S, Bommer JJ (2007) Prediction of elastic displacement response spectra in Europe and the Middle East. Earthquake Engineering and Structural Dynamics 36(10):12751301, DOI 10.1002/eqe.679 
Akkar S, Bommer JJ (2010) Empirical equations for the prediction of PGA, PGV and spectral accelerations in Europe, the Mediterranean region and the Middle East. Seismological Research Letters 81(2):195-206

Akkar S, Çağnan Z (2010) A local ground-motion predictive model for Turkey and its comparison with other regional and global ground-motion models. Bulletin of the Seismological Society of America 100(6):2978-2995

Al-Qaryouti MY (2008) Attenuation relations of peak ground acceleration and velocity in the Southern Dead Sea Transform region. Arabian Journal of Geosciences 1(2):111-117

Alavi AH, Gandomi AH, Modaresnezhad M, Mousavi M (2011) New ground-motion prediction equations using multi expression programing. Journal of Earthquake Engineering 15:511-536, DOI 10.1080/13632469.2010.526752

Alavi B, Krawinkler H (2000) Consideration of near-fault ground motion effects in seismic design. In: Proceedings of Twelfth World Conference on Earthquake Engineering

Ambraseys NN, Free MW (1997) Surface-wave magnitude calibration for European region earthquakes. Journal of Earthquake Engineering 1(1):1-22

Ambraseys NN, Smit P, Douglas J, Margaris B, Sigbjörnsson R, Ólafsson S, Suhadolc P, Costa G (2004) Internet site for European strong-motion data. Bollettino di Geofisica Teorica ed Applicata 45(3):113-129

Arias A (1970) A measure of earthquake intensity. In: Hansen R (ed) Seismic Design for Nuclear Power Plants, The M.I.T. Press, pp 438-483

Atkinson GM (2008) Ground-motion prediction equations for eastern North America from a referenced empirical approach: Implications for epistemic uncertainty. Bulletin of the Seismological Society of America 98(3):1304-1318, DOI 10.1785/0120070199

Atkinson GM, Boore DM (1997a) Some comparisons between recent ground-motion relations. Seismological Research Letters 68(1)

Atkinson GM, Boore DM (1997b) Stochastic point-source modeling of ground motions in the Cascadia region. Seismological Research Letters 68(1):74-85

Atkinson GM, Boore DM (2006) Earthquake ground-motion prediction equations for eastern North America. Bulletin of the Seismological Society of America 96(6):2181-2205, DOI $10.1785 / 0120050245$

Atkinson GM, Boore DM (2011) Modifications to existing ground-motion prediction equations in light of new data. Bulletin of the Seismological Society of America 101(3):11211135, DOI $10.1785 / 0120100270$ 
Baker JW (2007) Correlation of ground motion intensity parameters used for predicting structural and geotechnical response. In: Kanda, Takada, Furuta (eds) Applications of Statistics and Probability in Civil Engineering, Taylor \& Francis Group, London

Bazzurro P, Cornell CA (2002) Vector-valued probabilistic seismic hazard analysis (VPSHA). In: Proceedings of 7th U.S. National Conference on Earthquake Engineering, paper No. 61

Beyer K, Bommer JJ (2006) Relationships between median values and between aleatory variabilities for different definitions of the horizontal component of motion. Bulletin of the Seismological Society of America 96(4A):1512-1522, DOI 10.1785/0120050210

Bindi D, Luzi L, Pacor F, Franceshina G, Castro RR (2006) Ground-motion predictions from empirical attenuation relationships versus recorded data: The case of the 1997-1998 Umbria-Marche, central Italy, strong-motion data set. Bulletin of the Seismological Society of America 96(3):984-1002, DOI 10.1785/0120050102

Bindi D, Parolai S, Grosser H, Milkereit C, Durukal E (2007) Empirical ground-motion prediction equations for northwestern Turkey using the aftershocks of the 1999 Kocaeli earthquake. Geophysical Research Letters 34(L08305), DOI 10.1029/2007GL029222

Bindi D, Luzi L, Pacor F (2009a) Interevent and interstation variability computed for the Italian Accelerometric Archive (ITACA). Bulletin of the Seismological Society of America 99(4):2471-2488, DOI 10.1785/0120080209

Bindi D, Luzi L, Pacor F, Sabetta F, Massa M (2009b) Towards a new reference ground motion prediction equation for Italy: Update of the Sabetta-Pugliese (1996). Bulletin of Earthquake Engineering 7(3):591-608, DOI 10.1007/s10518-009-9107-8

Bindi D, Luzi L, Massa M, Pacor F (2010) Horizontal and vertical ground motion prediction equations derived from the Italian Accelerometric Archive (ITACA). Bulletin of Earthquake Engineering 8(5):1209-1230, DOI 10.1007/s10518-009-9130-9

Boatwright J, Bundock H, Luetgert J, Seekins L, Gee L, Lombard P (2003) The dependence of PGA and PGV on distance and magnitude inferred from northern California ShakeMap data. Bulletin of the Seismological Society of America 93(5):2043-2055

Bommer JJ, Alarcón JE (2006) The prediction and use of peak ground velocity. Journal of Earthquake Engineering 10(1):1-31

Bommer JJ, Martínez-Pereira A (1999) The effective duration of earthquake strong motion. Journal of Earthquake Engineering 3(2):127-172 
Bommer JJ, Elnashai AS, Weir AG (2000) Compatible acceleration and displacement spectra for seismic design codes. In: Proceedings of Twelfth World Conference on Earthquake Engineering, paper no. 207

Bommer JJ, Scherbaum F, Bungum H, Cotton F, Sabetta F, Abrahamson NA (2005) On the use of logic trees for ground-motion prediction equations in seismic-hazard analysis. Bulletin of the Seismological Society of America 95(2):377-389, DOI 10.1785/0120040073

Bommer JJ, Stafford PJ, Alarcón JE (2009) Empirical equations for the prediction of the significant, bracketed, and uniform duration of earthquake ground motion. Bulletin of the Seismological Society of America 99(6):3217-3233, DOI 10.1785/0120080298

Boore DM, Atkinson GM (2007) Boore-Atkinson NGA ground motion relations for the geometric mean horizontal component of peak and spectral ground motion parameters. PEER Report 2007/01, Pacific Earthquake Engineering Research Center, College of Engineering, University of California, Berkeley

Boore DM, Atkinson GM (2008) Ground-motion prediction equations for the average horizontal component of PGA, PGV, and 5\%-damped PSA at spectral periods between $0.01 \mathrm{~s}$ and 10.0s. Earthquake Spectra 24(1):99-138, DOI 10.1193/1.2830434

Boore DM, Watson-Lamprey J, Abrahamson NA (2006) Orientation-independent measures of ground motion. Bulletin of the Seismological Society of America 96(4A):1502-1511, DOI $10.1785 / 0120050209$

Bragato PL, Slejko D (2005) Empirical ground-motion attenuation relations for the eastern Alps in the magnitude range 2.5-6.3. Bulletin of the Seismological Society of America 95(1):252-276, DOI 10.1785/0120030231

Bray JD, Rodriguez-Marek A (2004) Characterization of forward-directivity ground motions in the near-fault region. Soil Dynamics and Earthquake Engineering 24(11):815828, DOI 10.1016/j.soildyn.2004.05.001

Campbell KW (1990) Empirical prediction of near-source soil and soft-rock ground motion for the Diablo Canyon power plant site, San Luis Obispo county, California. Tech. rep., Dames \& Moore, Evergreen, Colorado, prepared for Lawrence Livermore National Laboratory. Not seen. Reported in Idriss (1993).

Campbell KW (1997) Empirical near-source attenuation relationships for horizontal and vertical components of peak ground acceleration, peak ground velocity, and pseudo-absolute acceleration response spectra. Seismological Research Letters 68(1):154-179 
Campbell KW (2000) Erratum: Empirical near-source attenuation relationships for horizontal and vertical components of peak ground acceleration, peak ground velocity, and pseudo-absolute acceleration response spectra. Seismological Research Letters 71(3):352-354

Campbell KW (2001) Erratum: Empirical near-source attenuation relationships for horizontal and vertical components of peak ground acceleration, peak ground velocity, and pseudo-absolute acceleration response spectra. Seismological Research Letters 72(4):474

Campbell KW, Bozorgnia Y (1994) Near-source attenuation of peak horizontal acceleration from worldwide accelerograms recorded from 1957 to 1993. In: Proceedings of the Fifth U.S. National Conference on Earthquake Engineering, vol III, pp 283-292

Campbell KW, Bozorgnia Y (2007) Campbell-Bozorgnia NGA ground motion relations for the geometric mean horizontal component of peak and spectral ground motion parameters. PEER Report 2007/02, Pacific Earthquake Engineering Research Center, College of Engineering, University of California, Berkeley

Campbell KW, Bozorgnia Y (2008a) Empirical ground motion model for shallow crustal earthquakes in active tectonic environments developed for the NGA project. In: Proceedings of Fourteenth World Conference on Earthquake Engineering, paper no. 03-02-0004

Campbell KW, Bozorgnia Y (2008b) NGA ground motion model for the geometric mean horizontal component of PGA, PGV, PGD and 5\% damped linear elastic response spectra for periods ranging from 0.01 to $10 \mathrm{~s}$. Earthquake Spectra 24(1):139-171, DOI $10.1193 / 1.2857546$

Campbell KW, Duke CM (1974a) Bedrock intensity attenuation and site factors from San Fernando earthquake records. Bulletin of the Seismological Society of America 64(1):173-185

Campbell KW, Duke CM (1974b) A reply. Bulletin of the Seismological Society of America 64(6):2009-2010

Chapman MC (1999) On the use of elastic input energy for seismic hazard analysis. Earthquake Spectra 15(4):607-635

Chiou B, Youngs R, Abrahamson N, Addo K (2010) Ground-motion attenuation model for small-to-moderate shallow crustal earthquakes in California and its implications on regionalization of ground-motion prediction models. Earthquake Spectra 26(4):907-926,

DOI 10.1193/1.3479930 
Chiou BSJ, Youngs RR (2008) An NGA model for the average horizontal component of peak ground motion and response spectra. Earthquake Spectra 24(1):173-215, DOI $10.1193 / 1.2894832$

Convertito V, De Matteis R, Romeo A, Zollo A, Iannaccone G (2007) A strong motion attenuation relation for early-warning application in the Campania region (southern Apennines). In: Gasparini P, Manfredi G, Zschau J (eds) Earthquake Early Warning Systems, Springer

Cornell CA, Banon H, Shakal AF (1979) Seismic motion and response prediction alternatives. Earthquake Engineering and Structural Dynamics 7(4):295-315

Cotton F, Scherbaum F, Bommer JJ, Bungum H (2006) Criteria for selecting and adjusting ground-motion models for specific target regions: Application to central Europe and rock sites. Journal of Seismology 10(2):137-156, DOI 10.1007/s10950-005-9006-7

Danciu L, Tselentis GA (2007a) Engineering ground-motion parameters attenuation relationships for Greece. Bulletin of the Seismological Society of America 97(1B):162-183, DOI $10.1785 / 0120040087$

Danciu L, Tselentis GA (2007b) Engineering ground-motion parameters attenuation relationships for Greece. In: Proceedings of the International Symposium on Seismic Risk Reduction: The JICA Technical Cooperation Project in Romania, pp 327-334, paper ID 26

Dobry R, Idriss IM, Ng E (1978) Duration characteristics of horizontal components of strong-motion earthquake records. Bulletin of the Seismological Society of America 68(5):1487-1520

Douglas J (2010) Consistency of ground-motion predictions from the past four decades. Bulletin of Earthquake Engineering 8(6):1515-1526, DOI 10.1007/s10518-010-9195-5

Douglas J (2011) Ground-motion prediction equations 1964-2010. Final report RP-59356FR, BRGM, Orléans, France, URL http://www.brgm.fr/publication/rechRapportSP.jsp

Ellsworth WL, Celebi M, Evans JR, Jensen EG, Kayen R, Metz MC, Nyman DJ, Roddick JW, Spudich P, Stephens CD (2004) Near-field ground motion of the 2002 Denali Fault, Alaska, earthquake recorded at Pump Station 10. Earthquake Spectra 20(3):597615, DOI 10.1193/1.1778172

Emolo A, Convertito V, Cantore L (2011) Ground-motion predictive equations for lowmagnitude earthquakes in the Campania-Lucania area, southern Italy. Journal of Geophysics and Engineering 8:46-60, DOI 10.1088/1742-2132/8/1/007 
Esteva L, Rosenblueth E (1964) Espectros de temblores a distancias moderadas y grandes. Boletin Sociedad Mexicana de Ingenieria Sesmica 2:1-18, in Spanish.

Faccioli E (1983) Measures of strong ground motion derived from a stochastic source model. Soil Dynamics and Earthquake Engineering 2(3):135-149

Faccioli F, Paolucci R, Rey J (2004) Displacement spectra for long periods. Earthquake Spectra 20(2):347-376

Foulser-Piggott R, Stafford PJ (2012) A predictive model for Arias intensity at multiple sites and consideration of spatial correlations. Earthquake Engineering and Structural Dynamics 41(3):431-451, DOI 10.1002/eqe.1137

Frisenda M, Massa M, Spallarossa D, Ferretti G, Eva C (2005) Attenuation relationships for low magnitude earthquakes using standard seismometric records. Journal of Earthquake Engineering 9(1):23-40

Frohlich C, Apperson KD (1992) Earthquake focal mechanisms, moment tensors, and the consistency of seismic activity near plate boundaries. Tectonics 11(2):279-296

Fukushima S, Hayashi T, Yashiro H (2007) Seismic hazard analysis based on the joint probability density function of PGA and PGV. In: Transactions, SMiRT 19, paper \# M03/1

García D, Singh SK, Herráiz M, Ordaz M, Pacheco JF (2005) Inslab earthquakes of central Mexico: Peak ground-motion parameters and response spectra. Bulletin of the Seismological Society of America 95(6):2272-2282, DOI 10.1785/0120050072

Gaull BA (1988) Attenuation of strong ground motion in space and time in southwest Western Australia. In: Proceedings of Ninth World Conference on Earthquake Engineering, vol II, pp 361-366

Gaull BA, Michael-Leiba MO, Rynn JMW (1990) Probabilistic earthquake risk maps of Australia. Australian Journal of Earth Sciences 37:169-187, not seen. Cited in Musson and Cecić (2002).

Gehl P, Seyedi DM, Douglas J (2011) Vector-valued fragility functions for seismic risk evaluation. Bulletin of Earthquake Engineering Submitted

Ghanat S (2011) Duration characteristics of the mean horizontal component of shallow crustal earthquake records in active tectonic regions. $\mathrm{PhD}$ thesis, Arizona State University, USA

Ghodrati Amiri G, Mahdavian A, Dana FM (2007a) Attenuation relationships for Iran. Journal of Earthquake Engineering 11(4):469-492, DOI 10.1080/13632460601034049 
Ghodrati Amiri G, Mahdavian A, Dana FM (2007b) Response on the Discussion of 'Attenuation relationships for Iran'. Journal of Earthquake Engineering 11(6):1036-1037, DOI 10.1080/13632460701647476

Ghodrati Amiri G, Khorasani M, Mirza Hessabi M, Razavian Amrei SA (2010) Groundmotion prediction equations of spectral ordinates and Arias intensity for Iran. Journal of Earthquake Engineering 14(1):1-29, DOI 10.1080/13632460902988984

Gregor N, Bolt B (1997) Peak strong motion attenuation relations for horizontal and vertical ground displacements. Journal of Earthquake Engineering 1(2):275-292

Gregor N, Silva W, Darragh B (2002) Development of attenuation relations for peak particle velocity and displacement. A pearl report to pg\&e/cec/caltrans., Pacific Engineering and Analysis, El Cerrito, U.S.A., URL http://www.pacificengineering.org/rpts_page1.shtml

Hasegawa HS, Basham PW, Berry MJ (1981) Attenuation relations for strong seismic ground motion in Canada. Bulletin of the Seismological Society of America 71(6):19431962

Hernandez B, Cotton F (2000) Empirical determination of the ground shaking duration due to an earthquake using strong motion accelerograms for engineering applications. In: Proceedings of Twelfth World Conference on Earthquake Engineering, paper no. 2254/4/A

Huo JR (1989) The characteristics of near field strong earthquake ground motion. PhD thesis, Institute of Engineering and Mechanics, China Seismological Bureau, China, in Chinese

Hwang H, Lin CK, Yeh YT, Cheng SN, Chen KC (2004) Attenuation relations of Arias intensity based on the Chi-Chi Taiwan earthquake data. Soil Dynamics and Earthquake Engineering 24:509-517

Idriss IM (1978) Characteristics of earthquake ground motions. In: Proceedings of the ASCE Geotechnical Engineering Division Speciality Conference: Earthquake Engineering and Soil Dynamics, vol III, pp 1151-1265

Idriss IM (1993) Procedures for selecting earthquake ground motions at rock sites. Tech. Rep. NIST GCR 93-625, National Institute of Standards and Technology

Iervolino I, Giorgio M, Galasso C, Manfredi G (2010) Conditional hazard maps for secondary intensity measures. Bulletin of the Seismological Society of America 100(6):3312-3319, DOI 10.1785/0120090383

Jibson RW (1987) Summary of research on the effects of topographic amplification of earthquakes shaking on slope stability. Open-File Report 87-268, US Geological Survey, 
Menlo Park, California, USA

Jin X, Kang LC, Ou YP (2008) Ground motion attenuation relation for small to moderate earthquakes in Fujian region, China. Acta Seismologica Sinica 21(3):283-295, DOI $10.1007 / \mathrm{s} 11589-008-0283-4$

Joyner WB, Boore DM (1981) Peak horizontal acceleration and velocity from strong-motion records including records from the 1979 Imperial Valley, California, earthquake. Bulletin of the Seismological Society of America 71(6):2011-2038

Joyner WB, Boore DM (1988) Measurement, characterization, and prediction of strong ground motion. In: Proceedings of Earthquake Engineering \& Soil Dynamics II, Geotechnical Division, ASCE, pp 43-102

Joyner WB, Boore DM (1993) Methods for regression analysis of strong-motion data. Bulletin of the Seismological Society of America 83(2):469-487

Joyner WB, Fumal TE (1984) Use of measured shear-wave velocity for predicting geologic site effects on strong ground motion. In: Proceedings of Eighth World Conference on Earthquake Engineering, vol II, pp 777-783

Joyner WB, Fumal TE (1985) Predictive mapping of earthquake ground motion. In: Evaluating Earthquake Hazards in the Los Angeles Region - An Earth Science Perspective, no. 1360 in U.S. Geological Survey Professional Paper, United States Government Printing Office, Washington, pp 203-220

Kamiyama M (1984) Effects of subsoil conditions and other factors on the duration of earthquake ground shakings. In: Proceedings of Eighth World Conference on Earthquake Engineering, vol II, pp 793-800

Kamiyama M (1995) An attenuation model for the peak values of strong ground motions with emphasis on local soil effects. In: Proceedings of the First International Conference on Earthquake Geotechnical Engineering, vol 1, pp 579-585

Kamiyama M, O’Rourke M, Flores-Berrones R (1992) A semi-empirical analysis of strongmotion peaks in terms of seismic source, propagation path and local site conditions. Tech. Rep. NCEER-92-0023, National Center for Earthquake Engineering Research

Kanno T, Narita A, Morikawa N, Fujiwara H, Fukushima Y (2006) A new attenuation relation for strong ground motion in Japan based on recorded data. Bulletin of the Seismological Society of America 96(3):879-897, DOI 10.1785/0120050138

Kawashima K, Aizawa K, Takahashi K (1984) Attenuation of peak ground motion and absolute acceleration response spectra. In: Proceedings of Eighth World Conference on Earth- 
quake Engineering, vol II, pp 257-264

Kawashima K, Aizawa K, Takahashi K (1986) Attenuation of peak ground acceleration, velocity and displacement based on multiple regression analysis of Japanese strong motion records. Earthquake Engineering and Structural Dynamics 14(2):199-215

Kayen RE, Mitchell JK (1997) Assessment of liquefaction potential during earthquakes by Arias intensity. Journal of Geotechnical and Geoenvironmental Engineering, ASCE 123(12):1162-1175, not seen

Kempton JJ, Stewart JP (2006) Prediction equations for significant duration of earthquake ground motions considering site and near-source effects. Earthquake Spectra 22(4):9851013, DOI 10.1193/1.2358175

Lee CT, Hsieh BS, Sung CH, Lin PS (2012) Regional Arias intensity attenuation relationship for Taiwan considering $V_{S 30}$. Bulletin of the Seismological Society of America 102(1):129-142, DOI 10.1785/0120100268

Lee J (2009) Engineering charaterization of earthquake ground motions. PhD thesis, University of Michigan, USA

Lee VW, Trifunac MD, Todorovska MI, Novikova EI (1995) Empirical equations describing attenuation of peak of strong ground motion, in terms of magnitude, distance, path effects and site conditions. Tech. Rep. CE 95-02, Department of Civil Engineering, University of Southern California, Los Angeles, California, U.S.A.

Liang J, Hao H, Gaull BA, Sinadinovski C (2008) Estimation of strong ground motions in southwest Western Australia with a combined Green's function and stochastic approach. Journal of Earthquake Engineering 12(3):382-405

Lin, Lee (2004) Unknown. Original reference not seen. Cited in 'Attenuation Relationship of Arias Intensity for Taiwan' by Hsieh, P.-S. (2007)

Liu KS, Tsai YB (2005) Attenuation relationships of peak ground acceleration and velocity for crustal earthquakes in Taiwan. Bulletin of the Seismological Society of America 95(3):1045-1058, DOI 10.1785/0120040162

Margaris B, Papazachos C, Papaioannou C, Theodulidis N, Kalogeras I, Skarlatoudis A (2002a) Ground motion attenuation relations for shallow earthquakes in Greece. In: Proceedings of the XXVIII General Assembly of the European Seismological Commission (ESC)

Margaris B, Papazachos C, Papaioannou C, Theodulidis N, Kalogeras I, Skarlatoudis A (2002b) Ground motion attenuation relations for shallow earthquakes in Greece. In: Pro- 
ceedings of Twelfth European Conference on Earthquake Engineering, paper reference 385

Massa M, Morasca P, Moratto L, Marzorati S, Costa G, Spallarossa D (2008) Empirical ground-motion prediction equations for northern Italy using weak- and strong-motion amplitudes, frequency content, and duration parameters. Bulletin of the Seismological Society of America 98(3):1319-1342, DOI 10.1785/0120070164

McGarr A, Fletcher JB (2005) Development of ground-motion prediction equations relevant to shallow mining-induced seismicity in the Trail Mountain area, Emery County, Utah. Bulletin of the Seismological Society of America 95(1):31-47, DOI 10.1785/0120040046

McGuire RK (1977) Seismic design spectra and mapping procedures using hazard analysis based directly on oscillator response. Earthquake Engineering and Structural Dynamics $5: 211-234$

McGuire RK (1978) Seismic ground motion parameter relations. Journal of The Geotechnical Engineering Division, ASCE 104(GT4):481-490

McGuire RK, Barnhard TP (1979) The usefulness of ground motion duration in prediction of severity of seismic shaking. In: Proceedings of the Second U.S. National Conference on Earthquake Engineering, pp 713-722

Megawati K (2007) Hybrid simulations of ground motions from local earthquakes affecting Hong Kong. Bulletin of the Seismological Society of America 97(4):1293-1307, DOI $10.1785 / 0120060129$

Megawati K, Pan TC (2010) Ground-motion attenuation relationship for the Sumatran megathrust earthquakes. Earthquake Engineering and Structural Dynamics 39:827-845, DOI 10.1002/eqe.967

Megawati K, Pan TC, Koketsu K (2003) Response spectral attenuation relationships for Singapore and the Malay peninsula due to distant Sumatran-fault earthquakes. Earthquake Engineering and Structural Dynamics 32(14):2241-2265

Megawati K, Pan TC, Koketsu K (2005) Response spectral attenuation relationships for Sumatran-subduction earthquakes and the seismic hazard implications to Singapore and Kuala Lumpur. Soil Dynamics and Earthquake Engineering 25(1):11-25

Mezcua J, García Blanco RM, Rueda J (2008) On the strong ground motion attenuation in Spain. Bulletin of the Seismological Society of America 98(3):1343-1353, DOI $10.1785 / 0120070169$ 
Midorikawa S (1993) Preliminary analysis for attenuation of ground velocity on stiff site. In: Proceedings of the International Workshop on Strong Motion Data, vol 2, pp 39-48, not seen

Midorikawa S, Ohtake Y (2004) Variance of peak ground acceleration and velocity in attenuation relationships. In: Proceedings of Thirteenth World Conference on Earthquake Engineering, paper no. 0325

Molas GL, Yamazaki F (1995) Attenuation of earthquake ground motion in Japan including deep focus events. Bulletin of the Seismological Society of America 85(5):1343-1358

Musson RMW, Cecić I (2002) Macroseismology. In: Lee WHK, Kanamori H, Jennings PC, Kisslinger C (eds) International Handbook of Earthquake and Engineering Seismology, vol 81A, Academic Press, San Diego, USA, chap 49, pp 807-822

Nguyen LM, Lin TL, Wu YM, Huang BS, Chang CH, Huang WG, Le TS, Nguyen QC, Dinh VT (2012) The first peak ground motion attenuation relationships for north of Vietnam. Journal of Asian Earth Sciences 43(1):241-253, DOI 10.1016/j.jseaes.2011.09.012

Niazi M, Bozorgnia Y (1991) Behaviour of near-source peak horizontal and vertical ground motions over SMART-1 array, Taiwan. Bulletin of the Seismological Society of America 81(3):715-732

Nuttli OW, Herrmann RB (1987) Ground motion relations for eastern North American earthquakes. In: Proceedings of the Third International Conference on Soil Dynamics \& Earthquake Engineering, vol II, pp 231-241

Ohno S, Ohta T, Ikeura T, Takemura M (1993) Revision of attenuation formula considering the effect of fault size to evaluate strong motion spectra in near field. Tectonophysics 218:69-81

Ólafsson S, Sigbjörnsson R (1999) A theoretical attenuation model for earthquake-induced ground motion. Journal of Earthquake Engineering 3(3):287-315

Paciello A, Rinaldis D, Romeo R (2000) Incorporating ground motion parameters related to earthquake damage into seismic hazard analysis. In: Proceedings of the Sixth International Conference on Seismic Zonation, pp 321-326

Pankow KL, Pechmann JC (2004) The SEA99 ground-motion predictive relations for extensional tectonic regimes: Revisions and a new peak ground velocity relation. Bulletin of the Seismological Society of America 94(1):341-348

Pankow KL, Pechmann JC (2006) Erratum: The SEA99 ground-motion predictive relations for extensional tectonic regimes: Revisions and a new peak ground velocity relation. Bul- 
letin of the Seismological Society of America 96(1):364, DOI 10.1785/0120050184

Paolucci R, Rovelli A, Faccioli E, Cauzzi C, Finazzi D, Vanini M, Di Alessandro C, Calderoni G (2008) On the reliability of long period spectral ordinates from digital accelerograms. Earthquake Engineering and Structural Dynamics 37(5):697-710

Pousse G, Bonilla LF, Cotton F, Margerin L (2006) Non stationary stochastic simulation of strong ground motion time histories including natural variability: Application to the K-net Japanese database. Bulletin of the Seismological Society of America 96(6):2103-2117, DOI 10.1785/0120050134

Power M, Chiou B, Abrahamson N, Bozorgnia Y, Shantz T, Roblee C (2008) An overview of the NGA project. Earthquake Spectra 24(1):3-21, DOI 10.1193/1.2894833

Rajabi AM, Khamehchiyan M, Mahdavifar MR, Del Gaudio V (2010) Attenuation relation of Arias intensity for Zagros Mountains region (Iran). Soil Dynamics and Earthquake Engineering 30:110-118, DOI 10.1016/j.soildyn.2009.09.008

Rinaldis D, Berardi R, Theodulidis N, Margaris B (1998) Empirical predictive models based on a joint Italian \& Greek strong-motion database: I, peak ground acceleration and velocity. In: Proceedings of Eleventh European Conference on Earthquake Engineering

Rupakhety R, Sigurdsson SU, Papageorgiou AS, Sigbjörnsson R (2011) Quantification of ground-motion parameters and response spectra in the near-fault region. Bulletin of Earthquake Engineering 9:893-930, DOI 10.1007/s10518-011-9255-5

Sabetta F, Pugliese A (1996) Estimation of response spectra and simulation of nonstationary earthquake ground motions. Bulletin of the Seismological Society of America 86(2):337352

Sadigh RK, Egan JA (1998) Updated relationships for horizontal peak ground velocity and peak ground displacement for shallow crustal earthquakes. In: Proceedings of the Sixth U.S. National Conference on Earthquake Engineering

Sarma SK, Srbulov M (1998) A uniform estimation of some basic ground motion parameters. Journal of Earthquake Engineering 2(2):267-287

Si H, Midorikawa S (1999) New attenuation relationships for peak ground acceleration and velocity considering effects of fault type and site condition. Journal of Structural and Construction Engineering, AIJ 523:63-70, in Japanese with English abstract. Not seen.

Si H, Midorikawa S (2000) New attenuation relations for peak ground acceleration and velocity considering effects of fault type and site condition. In: Proceedings of Twelfth World Conference on Earthquake Engineering, paper No. 0532 
Silva W, Gregor N, Darragh R (2002) Development of regional hard rock attenuation relations for central and eastern North America. Tech. rep., Pacific Engineering and Analysis

Singh RP, Aman A, Prasad YJJ (1996) Attenuation relations for strong seismic ground motion in the Himalayan region. Pure and Applied Geophysics 147(1):161-180

Snæbjörnsson JT, Sigbjörnsson R (2008) The duration characteristics of earthquake ground motions. In: Proceedings of Fourteenth World Conference on Earthquake Engineering

Somerville PG (1998) Development of an improved representation of near fault ground motions. In: Proceedings of the SMIP98 Seminar on Utilization of Strong Motion Data, pp $1-20$

Stafford PJ, Berrill JB, Pettinga JR (2009) New predictive equations for Arias intensity from crustal earthquakes in New Zealand. Journal of Seismology 13(1):31-52, DOI 10.1007/s10950-008-9114-2

Stewart JP, Chiou SJ, Bray JD, Graves RW, Somerville PG, Abrahamson NA (2001) Ground motion evaluation procedures for performance-based design. PEER Report 2001/09, Pacific Earthquake Engineering Research Center, College of Engineering, University of California, Berkeley, USA

Theodulidis N, Lekidis V, Margaris B, Papazachos C, Papaioannou C, Dimitriu P (1998) Seismic hazard assessment and design spectra for the Kozani-Grevena region (Greece) after the earthquake of May 13, 1995. Journal of Geodynamics 26(2-4):375-391

Theodulidis NP, Papazachos BC (1992) Dependence of strong ground motion on magnitudedistance, site geology and macroseismic intensity for shallow earthquakes in Greece: I, peak horizontal acceleration, velocity and displacement. Soil Dynamics and Earthquake Engineering 11:387-402

Toro GR, Silva WJ (2001) Scenario earthquakes for Saint Louis, MO, and Memphis, TN, and seismic hazard maps for the central United States region including the effect of site conditions. Tech. rep., research supported by the U.S. Geological Survey (USGS), under award number 1434-HQ-97-GR-02981

Travasarou T, Bray JD, Abrahamson NA (2003) Empirical attenuation relationship for Arias intensity. Earthquake Engineering and Structural Dynamics 32:1133-1155, DOI 10.1002/eqe. 270

Trifunac MD (1976) Preliminary analysis of the peaks of strong earthquake ground motion - dependence of peaks on earthquake magnitude, epicentral distance, and recording site conditions. Bulletin of the Seismological Society of America 66(1):189-219 
Trifunac MD, Brady AG (1975a) On the correlation of peak acceleration of strong motion with earthquake magnitude, epicentral distance and site conditions. In: Proceedings of the U.S. National Conference on Earthquake Engineering, pp 43-52

Trifunac MD, Brady AG (1975b) A study on the duration of strong earthquake ground motion. Bulletin of the Seismological Society of America 65(3):581-626

Trifunac MD, Brady AG (1976) Correlations of peak acceleration, velocity and displacement with earthquake magnitude, distance and site conditions. Earthquake Engineering and Structural Dynamics 4(5):455-471

Tromans I (2004) Behaviour of buried water supply pipelines in earthquake zones. PhD thesis, University of London

Tromans IJ, Bommer JJ (2002) The attenuation of strong-motion peaks in Europe. In: Proceedings of Twelfth European Conference on Earthquake Engineering, paper no. 394

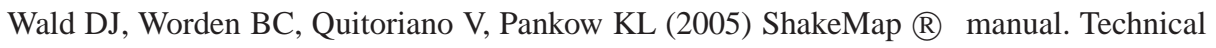
Manual, users guide, and software guide Version 1.0, USGS Techniques and Methods 12-A1, URL http://pubs.usgs.gov/tm/2005/12A01/

Wilson RC (1993) Relation of Arias intensity to magnitude and distance in California. OpenFile Report 93-556, US Geological Survey, Menlo Park, California, USA

Wilson RC, Keefer DK (1985) Predicting areal limits of earthquake-induced landsliding. In: Professional Paper, 1360, US Geological Survey, pp 317-345

Wu YM, Shin TC, Chang CH (2001) Near real-time mapping of peak ground acceleration and peak ground velocity following a strong earthquake. Bulletin of the Seismological Society of America 91(5):1218-1228

Yaghmaei-Sabegh S, Shoghian Z, Sheikh MN (2012) A new model for the prediction of earthquake ground-motion duration in Iran. Natural Hazards DOI 10.1007/s11069-0119990-6, in press

Zonno G, Montaldo V (2002) Analysis of strong ground motions to evaluate regional attenuation relationships. Annals of Geophysics 45(3-4):439-454 


\section{A GMPEs considered here}

$\mathrm{H}$ Number of horizontal records (if both horizontal components are used then multiply by two to get total number)

$\mathrm{V}$ Number of vertical components

E Number of earthquakes

$M_{\min }$ Magnitude of smallest earthquake

$M_{\max }$ Magnitude of largest earthquake

$M$ scale Magnitude scale (scales in brackets refer to those scales which the main $M$ values were sometimes converted from, or used without conversion, when no data existed), where:

$m_{b}$ Body-wave magnitude

$M_{C L}$ Coda length magnitude

$M_{D}$ Duration magnitude

M JMA Japanese Meteorological Agency magnitude

$M_{L}$ Local magnitude

$M_{b L g}$ Magnitude calculated using Lg amplitudes on short-period vertical seismographs

$M_{s}$ Surface-wave magnitude

$M_{w}$ Moment magnitude

$r_{\min }$ Shortest source-to-site distance

$r_{\max }$ Longest source-to-site distance

$r$ scale Distance metric, where (when available the de facto standard abbreviations of Abrahamson and Shedlock (1997) are used):

$r_{\text {epi }}$ Epicentral distance

$r_{j b}$ Distance to projection of rupture plane on surface (Joyner and Boore, 1981)

$r_{\text {hypo }}$ Hypocentral (or focal) distance

$r_{q}$ Equivalent hypocentral distance (EHD) (Ohno et al, 1993)

$r_{\text {rup }}$ Distance to rupture plane

$r_{\text {seis }}$ Distance to seismogenic rupture plane (assumes near-surface rupture in sediments is non-seismogenic)

(Campbell, 1997)

$r_{\text {slip }}$ Distance to point of highest slip

S Number of different site conditions modelled, where:

C Continuous classification

I Individual classification for each site

C Use of the two horizontal components of each accelerogram [see Beyer and Bommer (2006)], where:

A Arithmetic mean

B Both components

C Randomly chosen component

$\mathrm{G}$ Geometric mean

I50 GMrotI50 (Boore et al, 2006)

L Larger component

L3 Larger component amongst three components (including vertical) 
M Mean (not stated what type)

$\mathrm{N}$ Fault normal

O Randomly oriented component

$\mathrm{R}$ Resolved component

$\mathrm{T}$ Transverse (SH) component

U Unknown

R Regression method used, where:

1 Ordinary one-stage

1M Maximum likelihood one-stage or random-effects (Abrahamson and Youngs, 1992; Joyner and Boore, 1993)

1WM Weighted maximum-likelihood one-stage

2 Two-stage (Joyner and Boore, 1981)

2M Maximum likelihood two-stage (Joyner and Boore, 1993)

2W Two-stage with second staged weighted as described in Joyner and Boore (1988)

O Other (see section referring to study)

$\mathrm{U}$ Unknown (often probably ordinary one-stage regression)

M Source mechanisms (and tectonic type) of earthquakes (letters in brackets refer to those mechanism that are separately modelled), where:

A All (this is assumed if no information is given in the reference)

AS Aftershock

B Interslab

C Shallow crustal

$\mathrm{F}$ Interface

HW Hanging wall

I Intraplate

M Mining-induced

$\mathrm{N}$ Normal

O Oblique or odd (Frohlich and Apperson, 1992)

R Reverse

Rake Rake angle explicitly given

S Strike-slip

T Thrust

U Unspecified

'+' refers to extra records from outside region used to supplement data. (...) refer either to magnitudes of supplementing records or to those used for part of analysis. * means information is approximate because either read from graph or found in another way. 
Table 1: Characteristics of GMPEs considered here

\begin{tabular}{|c|c|c|c|c|c|c|c|c|c|c|c|c|c|c|c|c|}
\hline No. & Reference & Area & $\mathrm{H}$ & $\mathrm{v}$ & E & $M_{\min }$ & $M_{\max }$ & $\begin{array}{l}M \\
\text { scale }\end{array}$ & $r_{\min }$ & $r_{\text {max }}$ & $r$ scale & s & c & $\mathrm{R}$ & M & IM \\
\hline 1 & Esteva and Rosenblueth (1964) & W. USA & $46^{*}$ & - & $\mathrm{U}$ & $\mathrm{U}$ & $\mathrm{U}$ & $\mathrm{U}$ & $15^{*}$ & $450^{*}$ & $r_{\text {hypo }}$ & 1 & $\mathrm{U}$ & $\mathrm{U}$ & A & PGV \\
\hline 2 & Campbell and Duke (1974a,b) & W. USA & \multicolumn{3}{|c|}{ Hybrid approach } & $M_{s}$ & 4.5 & $\mathrm{u}$ & 10 & 47 & $r_{\text {hypo }}$ & 5 & $\mathrm{~A}$ & $\mathrm{o}$ & A & $\mathrm{AI}$ \\
\hline 3 & 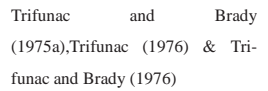 & W. USA & 181 & 181 & 57 & 3.8 & 7.7 & $\begin{array}{l}\text { Mostly } \\
M_{L}\end{array}$ & $6^{2 *}$ & $400^{3 *}$ & $r_{e p i}$ & 3 & B & o & $\mathrm{A}$ & $\begin{array}{l}\mathrm{PGV}, \\
\mathrm{PGD}\end{array}$ \\
\hline 4 & Trifunac and Brady (1975b) & W. USA & 188 & 188 & 48 & 3.8 & 7.7 & $\begin{array}{l}\text { Mostly } \\
M_{L}\end{array}$ & $6^{*}$ & $400^{*}$ & $r_{e p i}$ & 3 & B & $\mathrm{o}$ & A & $\begin{array}{l}\mathrm{AI}, \\
\mathrm{RSD}\end{array}$ \\
\hline 5 & McGuire (1977) & W. USA & 34 & - & 22 & 5.3 & 7.6 & $M_{L}$ & 14 & 125 & $r_{\text {hypo }}$ & 1 & B & $\mathrm{U}$ & A & $\begin{array}{l}\mathrm{PGV}, \\
\mathrm{PGD}\end{array}$ \\
\hline 6 & Dobry et al (1978) & W. USA & 84 & - & 14 & 4.7 & 7.6 & $M_{L}$ & 0.1 & 130 & rrup & 2 & B & 1 & A & RSD \\
\hline 7 & McGuire (1978) & W. USA & 70 & - & $17+*$ & $4.5^{*}$ & 7.7 & $\frac{\mathrm{u}^{4}}{\mathrm{n}}$ & $11^{*}$ & $210^{*}$ & $r_{\text {hypo }}$ & 2 & B & $\mathrm{U}$ & A & $\begin{array}{l}\text { PGV, } \\
\text { PGD }\end{array}$ \\
\hline 8 & McGuire and Barnhard (1979) & w. USA & 50 & - & $\mathrm{U}$ & $\mathrm{U}$ & $\mathrm{U}$ & $\mathrm{u}$ & $\mathrm{U}$ & $\mathrm{U}$ & $\begin{array}{l}r_{r u p} \\
\left(r_{\text {epi }}\right. \\
\text { for } \\
\text { some) }\end{array}$ & 2 & B & 1 & A & RSD \\
\hline 9 & Cornell et al (1979) & W. USA & 70 & - & $\mathrm{U}$ & $\mathrm{U}$ & $\mathrm{U}$ & $M_{L}$ & $\mathrm{U}$ & $\mathrm{u}$ & $r_{\text {hypo }}$ & 1 & C & $\mathrm{U}$ & A & $\begin{array}{l}\text { PGV, } \\
\text { PGD }\end{array}$ \\
\hline 10 & Hasegawa et al $(1981)$ & E. \& W. Canada & & Hybrid : & & $4^{*}$ & $7.6^{*}$ & $\mathrm{U}$ & $5^{*}$ & $400^{*}$ & $r_{\text {hypo }}$ & 1 & $\mathrm{U}$ & $\mathrm{o}$ & A & $\mathrm{PGV} \times 2$ \\
\hline 11 & Joyner and Boore (1981) & W. N. America & 182 & - & 23 & 5.0 & 7.7 & $\begin{array}{l}M_{w} \\
\left(M_{L}\right)\end{array}$ & 0.5 & 370 & $r_{j b}$ & 2 & $\mathrm{~L}$ & 2 & A & PGV \\
\hline 12 & Faccioli (1983) & $\begin{array}{l}\text { Worldwide } \\
\end{array}$ & & Hybrid : & & 4.7 & 7.7 & $M_{w}$ & $4^{*}$ & $95^{*}$ & $r_{\text {hypo }}$ & $\mathrm{c}$ & $\mathrm{R}$ & $\mathrm{o}$ & $\mathrm{A}$ & $\mathrm{AI}$ \\
\hline 13 & $\begin{array}{l}\text { Joyner and Fumal (1984) and } \\
\text { Joyner and Fumal (1985) }\end{array}$ & W. N. America & 182 & - & 23 & 5.0 & 7.7 & $\begin{array}{l}M_{w} \\
\left(M_{L}\right)\end{array}$ & 0.5 & 370 & $r_{j b}$ & $\overline{\mathrm{c}}$ & $\mathrm{L}$ & 2 & $\mathrm{~A}$ & 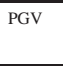 \\
\hline 14 & Kamiyama (1984) & Japan & 192 & - & $\mathrm{U}$ & 4.1 & 7.9 & $M_{J M A}$ & 10 & 310 & $r_{e p i}$ & $\mathrm{I}$ & B & 1 & A & RSD \\
\hline 15 & $\begin{array}{l}\text { Kawashima et al (1984) \& } \\
\text { Kawashima et al (1986) }\end{array}$ & Japan & 197 & - & 90 & 5.0 & 7.9 & $M_{\mathrm{JMA}}$ & $5^{*}$ & $550^{*}$ & $r_{e p i}$ & 3 & $\mathrm{R}$ & 1 & A & $\begin{array}{l}\text { PGV, } \\
\text { PGD }\end{array}$ \\
\hline 16 & Wilson and Keefer (1985) & W. USA & 30 & & 20 & 5.0 & 7.4 & $M_{w}$ & 6 & 130 & $r_{j b}$ & 1 & A & 1 & A & AI \\
\hline
\end{tabular}

${ }^{2}$ Note only valid for $R \geq 20 \mathrm{~km}$

${ }^{3}$ Note only valid for $R \leq 200 \mathrm{~km}$

${ }^{4}$ Idriss (1978) finds magnitudes to be mixture of $M_{L}, m_{b}$ and $M_{s}$. 
Table 1: continued

\begin{tabular}{|c|c|c|c|c|c|c|c|c|c|c|c|c|c|c|c|c|}
\hline No. & $\begin{array}{l}\text { Reference } \\
\end{array}$ & Area & $\mathrm{H}$ & $\mathrm{v}$ & $\mathrm{E}$ & $M_{\min }$ & $M_{\max }$ & $\begin{array}{l}M \\
\text { scale }\end{array}$ & $r_{\min }$ & $r_{\text {max }}$ & $r$ scale & $\mathrm{s}$ & C & $\mathrm{R}$ & M & $\mathrm{IM}$ \\
\hline 17 & Jibson (1987) & $\begin{array}{ll}\text { w. USA } \\
\end{array}$ & 31 & - & 21 & 5.0 & 7.4 & $M_{w}$ & 6 & 130 & $r_{j b}$ & 1 & $\mathrm{~A}$ & 1 & $\mathrm{~A}$ & $\mathrm{AI}$ \\
\hline 18 & Nuttli and Herrmann (1987) & E. N. America & & Simulatior & & $\mathrm{U}$ & $\mathrm{U}$ & $m_{b L g}$ & $\mathrm{U}$ & $\mathrm{U}$ & $r_{\text {hypo }}$ & 1 & G & 1 & A & PGV \\
\hline 19 & K.W. Campbell $(1988)^{5}$ & $\begin{array}{l}\text { Worldwide } \\
\end{array}$ & $\mathrm{U}$ & - & $\mathrm{U}$ & $\geq 5$ & $\mathrm{U}$ & $\begin{array}{l}M_{L} \\
\text { for } \\
M<< \\
6.0 \\
\text { and } \\
M_{S} \\
\text { other- } \\
\text { wise } \\
\end{array}$ & $\mathrm{u}$ & $<50$ & $r_{\text {seis }}$ & 2 & $\mathrm{M}$ & $\mathrm{U}$ & $\begin{array}{l}\text { A (S, } \\
\text { R) }\end{array}$ & PGV \\
\hline 20 & Gaull (1988) & S.W.W. Australia & $25+$ & - & $12+$ & 2.6 & 6.9 & $M_{L}$ & 2.5 & 175 & $r_{\text {hypo }}$ & 1 & $\mathrm{u}$ & $\mathrm{o}$ & $\mathrm{A}$ & PGV \\
\hline 21 & Нио (1989) & S. China & $\mathrm{U}$ & & $\mathrm{U}$ & $\mathrm{U}$ & U & $\mathrm{U}$ & $\mathrm{U}$ & $\mathrm{U}$ & $\mathrm{U}$ & 1 & G & 1 & A & PGV \\
\hline 22 & Campbell (1990) & Unknown & $\mathrm{u}$ & - & $\mathrm{U}$ & $\mathrm{u}$ & $\mathrm{U}$ & $\begin{array}{l}M_{L} \text { for } \\
M<6, \\
M<\text { for } \\
M \geq 6\end{array}$ & $\mathrm{U}$ & $\mathrm{U}$ & $r_{\text {seis }}$ & 1 & U & $\mathrm{u}$ & A & PGV \\
\hline 23 & Gaull et al (1990) & SE Australia & & Hybrid a & & $\mathrm{U}$ & $\mathrm{U}$ & $\begin{array}{c}\mathrm{u} \\
\end{array}$ & $\mathrm{U}$ & $\mathrm{U}$ & $r_{\text {hypo }}$ & 1 & $\mathrm{U}$ & $\mathrm{o}$ & A & PGV \\
\hline 24 & Niazi and Bozorgnia (1991) & SMART-1 array, Taiwan & 236 & 234 & 12 & 3.6 & 7.8 & $\begin{array}{l}M_{L} \\
\left(M_{D}\right) \\
\text { for } \\
M_{L}< \\
6.6, \\
\text { else } \\
M_{s}\end{array}$ & $3.1^{6}$ & $119.7^{6}$ & $r_{\text {hypo }}$ & 1 & M & $2 \mathrm{~W}$ & A & $\begin{array}{l}\text { PGV, } \\
\text { PGD }\end{array}$ \\
\hline 25 & $\begin{array}{l}\text { Kamiyama et al (1992) \& } \\
\text { Kamiyama (1995) }\end{array}$ & Japan & 357 & - & 82 & 4.1 & 7.9 & $M_{\mathrm{JMA}}$ & 3.4 & 413.3 & $r_{\text {hypo }}$ & I & B & $\mathrm{o}$ & A & $\begin{array}{l}\text { PGV, } \\
\text { PGD }\end{array}$ \\
\hline
\end{tabular}

\footnotetext{
${ }^{5}$ Reported in Joyner and Boore (1988)
}

${ }^{6}$ Distance to centre of array 
able 1: continued

\begin{tabular}{|c|c|c|c|c|c|c|c|c|c|c|c|c|c|c|c|c|}
\hline No. & Reference & Area & $\mathrm{H}$ & $\mathrm{v}$ & E & $M_{\min }$ & $M_{\max }$ & $\begin{array}{l}M \\
\text { scale }\end{array}$ & $r_{\min }$ & $r_{\max }$ & $r$ scale & s & c & $\mathrm{R}$ & м & IM \\
\hline 26 & Theodulidis and Papazachos (1992) & Greece+16 foreign & $105+16^{7}$ & - & $36+4$ & $\begin{array}{l}4.5 \\
(7.2)\end{array}$ & $\begin{array}{l}7.0 \\
(7.5)\end{array}$ & $\begin{array}{l}M_{s}, \\
M_{w}, \\
M_{\mathrm{JMA}}\end{array}$ & $1(48)$ & $\begin{array}{l}128 \\
(236)\end{array}$ & $r_{e p i}$ & 2 & B & $\mathrm{o}$ & A & $\begin{array}{l}\text { PGV, } \\
\text { PGD }\end{array}$ \\
\hline 27 & Midorikawa (1993) & Japan & $\mathrm{u}$ & - & $\mathrm{U}$ & 6.5 & 7.8 & $M_{w}$ & $\mathrm{u}$ & $\mathrm{u}$ & $r_{\text {rup }}$ & 1 & $\mathrm{u}$ & 1 & $\mathrm{~A}$ & PGV \\
\hline 28 & Wilson (1993) & W. USA & & Hybrid appr & & 5.3 & 7.5 & $M_{w}$ & $3^{*}$ & $100^{*}$ & $r_{j b}$ & 1 & G & $\mathrm{o}$ & $\mathrm{A}$ & $\mathrm{AI}$ \\
\hline 29 & Lee et al (1995) & W. N. America & 1926 & 1926 & 297 & 1.7 & 7.7 & $\begin{array}{l}\text { Usually } \\
M_{L} \\
\text { for } \\
M \leq \\
6.5 \\
\text { and } \\
M_{S} \text { for } \\
M> \\
6.5\end{array}$ & 2 & $200+$ & $r_{\text {hypo }}$ & $\begin{array}{l}9,3 \times \\
c\end{array}$ & $\mathrm{u}$ & 1 & A & $\begin{array}{l}\text { PGV, } \\
\text { PGD }\end{array}$ \\
\hline 30 & Molas and Yamazaki (1995) & Japan & 2166 & - & 387 & $4.1^{*}$ & $7.8^{*}$ & $M_{\mathrm{JMA}}$ & $8^{*}$ & $1000^{*}$ & $\begin{array}{l}r_{\text {rup }} \\
\text { for } 2 \\
\text { earth- } \\
\text { quakes, } \\
r_{\text {hypo }} \\
\text { other- } \\
\text { wise } \\
\end{array}$ & I & $\mathrm{L}$ & $\mathrm{o}$ & A & PGV \\
\hline 32 & $\begin{array}{l}\text { Sabetta and Pugliese (1996) } \\
\end{array}$ & Italy & 95 & 95 & 17 & 4.6 & 6.8 & $\begin{array}{l}M_{S} \text { if } \\
M_{L} \& \\
M_{s} \geq \\
5.5 \\
\text { else } \\
M_{L} \\
\end{array}$ & $\begin{array}{l}1.5, \\
1.5\end{array}$ & $\begin{array}{l}179, \\
180^{8}\end{array}$ & $\begin{array}{l}\text { Both } \\
r_{j b} \& \\
r_{e p i}\end{array}$ & 3 & $\mathrm{~L}$ & 1 & A & $\begin{array}{l}\text { PGV, } \\
\text { AI }\end{array}$ \\
\hline 33 & Singh et al (1996) & Himalayas & 86 & - & 5 & 5.7 & 7.2 & $m_{b}$ & 33.15 & 340.97 & $r_{\text {hypo }}$ & 1 & $\mathrm{u}$ & 1 & $\mathrm{~A}$ & PGV \\
\hline 34 & Atkinson and Boore (1997a) & E. N. America & & imulation app & & 4.0 & 7.0 & $M_{w}$ & 10 & 500 & $r_{\text {hypo }}$ & 2 & G & $\mathrm{O}$ & A & PGV \\
\hline
\end{tabular}


Table 1: continued

\begin{tabular}{|c|c|c|c|c|c|c|c|c|c|c|c|c|c|c|c|c|}
\hline No. & Reference & Area & $\mathrm{H}$ & $\mathrm{v}$ & E & $M_{\min }$ & $M_{\max }$ & $\begin{array}{l}M \\
\text { scale }\end{array}$ & $r_{\min }$ & $r_{\max }$ & $r$ scale & $\mathrm{s}$ & c & $\mathrm{R}$ & M & IM \\
\hline 35 & Atkinson and Boore (1997b) & Cascadia & \multicolumn{3}{|c|}{ Simulation approach } & 3.7 & 6.7 & $M_{w}$ & 10 & 400 & hypo & 2 & $\mathrm{G}$ & $\mathrm{o}$ & $\mathrm{A}$ & PGV \\
\hline 36 & $\begin{array}{l}\text { Campbell (1997), Campbell (2000), } \\
\text { Campbell (2001) \& Campbell and } \\
\text { Bozorgnia (1994) }\end{array}$ & Worldwide & 645 & 225 & $\begin{array}{l}\text { H:47, } \\
\text { V:26 }\end{array}$ & 4.7 & $\begin{array}{l}\text { H:8.0, } \\
\text { V:8.1 }\end{array}$ & $M_{w}$ & 3 & 60 & $r_{\text {seis }}$ & 3 & G & 1 & $\mathrm{~A}(\mathrm{~S}, \mathrm{R}, \mathrm{N})$ & PGV \\
\hline 37 & Gregor and Bolt (1997) & California & 110 & 110 & 12 & 5.4 & 7.2 & $M_{w}$ & $6^{*}$ & $200^{*}$ & $r_{\text {slip }}$ & 2 & $\mathrm{~T}, \mathrm{~V}$ & 1 & $\mathrm{R}, \mathrm{S}$ & PGD \\
\hline 38 & Kayen and Mitchell (1997) & W. USA & 66 & - & $\mathrm{U}$ & $\mathrm{U}$ & $\begin{array}{c}\mathrm{U} \\
\end{array}$ & $M_{w}$ & $1^{*}$ & $100^{*}$ & $r_{\text {rup }}$ & 3 & G & 1 & $\mathrm{~A}$ & $\mathrm{AI}$ \\
\hline 39 & Rinaldis et al (1998) & Italy \& Greece & $137^{*}$ & - & $24^{*}$ & 4.5 & 7 & $\begin{array}{l}M_{s} \text { or } \\
M_{w}\end{array}$ & 7 & 138 & $r_{e p i}$ & 2 & $\mathrm{U}$ & $\mathrm{o}$ & $\begin{array}{l}\mathrm{A} \\
(\mathrm{N}, \mathrm{ST})\end{array}$ & PGV \\
\hline 40 & Sadigh and Egan (1998) & California with 4 foreign & $960+4$ & - & $119+2$ & 3.8 & 7.4 & $M_{w}$ & 0.1 & $305^{9}$ & $\begin{array}{l}r_{r u p} \\
\text { for } \\
\text { some, } \\
r_{\text {hypo }} \\
\text { for } \\
\text { small } \\
\text { ones } \\
\end{array}$ & 2 & G & $\mathrm{u}$ & $\mathrm{A}(\mathrm{R}, \mathrm{SN})$ & $\begin{array}{l}\text { PGV, } \\
\text { PGD }\end{array}$ \\
\hline 41 & Sarma and Srbulov (1998) & Worldwide & $690^{10}$ & - & 113 & 3.9 & 7.7 & $\begin{array}{l}M_{s} \\
(\mathrm{U})\end{array}$ & 0 & 197 & $\begin{array}{l}r_{j b}, \\
r_{e p i} \\
\end{array}$ & 2 & B & 1 & A & $\mathrm{AI}$ \\
\hline 42 & Somerville (1998) & $\begin{array}{l}15 \text { mainly W. USA }+12 \text { sim- } \\
\text { ulated }\end{array}$ & 27 & - & 13 & 6.2 & 7.5 & $M_{w}$ & 0.1 & 10 & rrup & 1 & $\mathrm{~N}$ & 1 & A & PGV \\
\hline 43 & Theodulidis et al (1998) & $\begin{array}{l}\text { Kozani-Grevena (Greece) } \\
\end{array}$ & $232^{11}$ & - & $\mathrm{U}$ & 3.1 & 6.6 & $M_{w}$ & 1 & $140^{*}$ & $r_{e p i}$ & 1 & B & 1 & $\mathrm{~A}$ & PGV \\
\hline 44 & Chapman (1999) & W. N. America & 304 & - & 23 & 5.0 & 7.7 & $M_{w}$ & 0.1 & 189.4 & $r_{j b}$ & 3 & G & $2 \mathrm{M}$ & A & PGV \\
\hline 45 & Ólafsson and Sigbjörnsson (1999) & $\begin{array}{ll}\text { Iceland } \\
\end{array}$ & $88^{12}$ & - & 17 & 4.0 & 5.9 & $M_{w}$ & 2 & 112 & $r_{e p i}$ & 1 & B & 1 & $\mathrm{~A}$ & RSD \\
\hline 46 & Alavi and Krawinkler (2000) & $\begin{array}{l}15 \text { mainly W. USA }+12 \text { sim- } \\
\text { ulated }\end{array}$ & 27 & - & 13 & 6.2 & 7.5 & $M_{w}$ & 0.1 & 10 & rrup & 1 & $\mathrm{~N}$ & 1 & A & PGV \\
\hline 47 & Bommer et al (2000) & Europe \& Middle East & 183 & - & 43 & 5.5 & 7.9 & $M_{s}$ & 3 & 260 & $r_{j b}$ & 3 & $\mathrm{~L}$ & 1 & A & $\begin{array}{l}\text { PGV, } \\
\text { PGD }\end{array}$ \\
\hline
\end{tabular}

${ }^{9}$ Equations stated to be for distances up to $100 \mathrm{~km}$

10 Total number of components do not need to be multiplied by two.

11 Total number of components do not need to be multiplied by two

12 Total number of components do not need to be multiplied by two. 
Table 1: continued

\begin{tabular}{|c|c|c|c|c|c|c|c|c|c|c|c|c|c|c|c|c|}
\hline No. & Reference & Area & $\mathrm{H}$ & $\mathrm{v}$ & E & $M_{\min }$ & $M_{\max }$ & $\begin{array}{l}M \\
\text { scale }\end{array}$ & $r_{\min }$ & $r_{\text {max }}$ & $r$ scale & $\mathrm{s}$ & C & $\mathrm{R}$ & M & IM \\
\hline 48 & Hernandez and Cotton (2000) & Italy \& California & $272^{13}$ & - & $40^{*}$ & 3.2 & 7.4 & $\begin{array}{l}M_{L} \\
\text { for } \\
M<6, \\
M_{s} \\
\text { other- } \\
\text { wise }\end{array}$ & 1 & 109 & rrup & 2 & B & 1 & A & RSD \\
\hline 49 & Paciello et al (2000) & Greece \& Italy & 115 & - & 18 & 4.5 & $\mathrm{U}$ & $\begin{array}{l}M_{w} \text { or } \\
M_{s}\end{array}$ & $\mathrm{U}$ & $\mathrm{U}$ & $r_{e p i}$ & 2 & B & 1 & $\mathrm{~A}(\mathrm{~N})$ & $\begin{array}{l}\text { PGV, } \\
\text { PGD } \\
\text { AI }\end{array}$ \\
\hline 50 & Si and Midorikawa $(1999,2000)$ & Japan & 856 & - & 21 & 5.8 & 8.3 & $M_{w}$ & $0^{*}$ & $280^{*}$ & $\begin{array}{l}\text { Both } \\
r_{q} \text { \& } \\
r_{r u p}\end{array}$ & 2 & $\mathrm{~L}$ & $\mathrm{o}$ & A & $\mathrm{PGV}$ \\
\hline 51 & Toro and Silva (2001) & Central USA & & Simulatio & & 5.5 & 7.5 & $M_{w}$ & 1 & 400 & $r_{j b}$ & 1 & G & 1 & A & $\begin{array}{l}\mathrm{PGV} \\
\times 2\end{array}$ \\
\hline 52 & Wu et al (2001) & $\begin{array}{l}\text { Taiwan } \\
\end{array}$ & 1941 & - & 60 & 4.8 & 7.6 & $\begin{array}{l}M_{W} \\
\left(M_{L}\right)\end{array}$ & $0.05 *$ & $400^{*}$ & $\begin{array}{l}r_{r u p} \\
\left(r_{e p i}\right. \\
\text { for } \\
\text { some) }\end{array}$ & $1 \& I$ & $\mathrm{U}$ & $\mathrm{U}$ & A & PGV \\
\hline 53 & Gregor et al (2002) & $\begin{array}{l}\text { Shallow crustal worldwide } \\
\text { (mainly California) }\end{array}$ & 993 & 993 & 68 & 4.4 & 7.4 & $M_{w}$ & 0.1 & 267.3 & rrup & 2 & $\mathrm{U}$ & $1 \mathrm{M}$ & $\begin{array}{l}\mathrm{A}(\mathrm{S}, \\
\mathrm{R} / \mathrm{O}, \\
\mathrm{T})\end{array}$ & $\begin{array}{l}\text { PGV, } \\
\text { PGD }\end{array}$ \\
\hline 54 & $\begin{array}{l}\text { Margaris et al (2002a) \& Margaris } \\
\text { et al (2002b) }\end{array}$ & Greece & 744 & - & 142 & 4.5 & 7.0 & $M_{w}$ & 1 & 150 & $r_{e p i}$ & 3 & B & $\mathrm{o}$ & A & $\begin{array}{l}\text { PGV, } \\
\text { PGD }\end{array}$ \\
\hline 55 & Silva et al (2002) & Cen. and E. N. America & & Simulatio & & 4.5 & 8.5 & $M_{w}$ & 1 & 400 & $r_{j b}$ & 1 & G & 1 & A & $\begin{array}{l}\mathrm{PGV} \\
\times 5\end{array}$ \\
\hline 56 & Tromans and Bommer (2002) & Europe & 249 & - & 51 & 5.5 & 7.9 & $M_{s}$ & 1 & 359 & $r_{j b}$ & 3 & $\mathrm{~L}$ & 2 & A & $\begin{array}{l}\text { PGV } \\
\text { PGD }\end{array}$ \\
\hline 57 & Zonno and Montaldo (2002) & Umbria-Marche & 161 & - & 15 & 4.5 & 5.9 & $M_{L}$ & $2^{*}$ & $100^{*}$ & $r_{e p i}$ & 2 & $\mathrm{~L}$ & 2 & $\mathrm{~N}, \mathrm{O}$ & $\begin{array}{l}\mathrm{PGV}, \\
\mathrm{AI}\end{array}$ \\
\hline 58 & Megawati et al (2003) & Sumatran interface & & SS & & 4.0 & 8.0 & $M_{w}$ & 174 & 1379 & $r_{\text {rup }}$ & 1 & G & 1 & $\mathrm{~F}$ & PGV \\
\hline
\end{tabular}

13 Total number of components do not need to be multiplied by two. 
Table 1: continued

\begin{tabular}{|c|c|c|c|c|c|c|c|c|c|c|c|c|c|c|c|c|}
\hline No. & Reference & Area & $\mathrm{H}$ & $\mathrm{v}$ & E & $M_{\min }$ & $M_{\max }$ & $\begin{array}{l}M \\
\text { scale }\end{array}$ & $r_{\min }$ & $r_{\max }$ & $r$ scale & $\mathrm{s}$ & $\mathrm{C}$ & $\mathrm{R}$ & M & IM \\
\hline 59 & Boatwrighte tal (2003) & N. California & 4028 & - & 104 & 3.3 & 7.1 & $\begin{array}{l}\text { Mainly } \\
M_{w} \text {, } \\
M_{L} \\
\text { for } \\
\text { some }\end{array}$ & $1^{*}$ & $370^{*}$ & $r_{\text {hypo }}$ & 4 & $\mathrm{u}$ & $\mathrm{o}$ & A & PGV \\
\hline 60 & Travasarou et al (2003) & Mainly W. USA & 1208 & - & 75 & 4.7 & 7.6 & $M_{w}$ & $0.1^{*}$ & $200^{*}$ & rrup & 3 & A & $1 \mathrm{M}$ & $\begin{array}{l}\text { A }(N, \\
\text { R) }\end{array}$ & $\mathrm{AI}$ \\
\hline 61 & Bray and Rodriguez-Marek (2004) & Worldwide & 54 & - & 13 & 6.1 & 7.6 & $M_{w}$ & 0.1 & 17.6 & $M_{\text {rup }}$ & 2 & $\mathrm{~N}$ & $1 \mathrm{M}$ & $\mathrm{A}$ & PGV \\
\hline 62 & Hwang et al (2004) & Chi-Chi (Taiwan) & $221^{14}$ & - & 4 & 6.2 & 7.7 & $M_{w}$ & $\begin{array}{l}\mathrm{U} \\
\end{array}$ & $\mathrm{U}$ & $r_{j b}$ & 1 & $\mathrm{~A}$ & $2 \mathrm{M}$ & $\mathrm{A}$ & $\mathrm{AI}$ \\
\hline 63 & Lin and Lee (2004) & Taiwan & $\mathrm{U}$ & - & 41 & $\mathrm{U}$ & $\mathrm{U}$ & $\mathrm{U}$ & $\mathrm{U}$ & $\mathrm{U}$ & $r_{\text {rup }}$ & 1 & $\mathrm{U}$ & 1 & A & $\mathrm{AI}$ \\
\hline 64 & Midorikawa and Ohtake (2004) & Japan & 3335 & - & 33 & 5.5 & 8.3 & $M_{w}$ & $0^{*}$ & $300^{*}$ & rrup & 2 & $\mathrm{~L}$ & 1 & $\begin{array}{l}\text { A (C, } \\
\text { B, F) }\end{array}$ & PGV \\
\hline 65 & $\begin{array}{l}\text { Pankow and Pechmann (2004) and } \\
\text { Pankow and Pechmann (2006) }\end{array}$ & $\begin{array}{l}\text { Worldwide extensional } \\
\text { regimes }\end{array}$ & 142 & - & 39 & 5.1 & 7.2 & $M_{w}$ & 0 & 99.4 & $r_{j b}$ & 2 & G, $\mathrm{O}$ & $1 \mathrm{M}$ & NS & PGV \\
\hline 66 & Bragato and Slejko (2005) & $\begin{array}{l}\text { E Alps }\left(45.6-46.8^{\circ} \mathrm{N} \& 12-\right. \\
\left.14^{\circ} \mathrm{E}\right)\end{array}$ & 1402 & 3168 & 240 & 2.5 & 6.3 & $M_{L}$ & 0 & 130 & $\begin{array}{l}r_{j b} \& \\
r_{e p i}\end{array}$ & 1 & $\mathrm{R}$ & o & A & $\begin{array}{l}\text { PGV, } \\
\text { AI }\end{array}$ \\
\hline 67 & Frisenda et al (2005) & NW Italy & $6899^{15}$ & - & $>1152$ & $0.0^{*}$ & $5.1^{16}$ & $M_{L}$ & 0 & $300^{17}$ & $r_{\text {hypo }}$ & 2 & B & 1 & A & PGV \\
\hline 68 & García et al (2005) & Central Mexico & 277 & 277 & 16 & 5.2 & 7.4 & $M_{w}$ & $4^{*}$ & $400^{*}$ & $\begin{array}{l}r_{\text {rup }} \\
\text { for } \\
M_{w}> \\
6.5, \\
r_{\text {hypo }} \\
\text { other- } \\
\text { wise }\end{array}$ & 1 & $\mathrm{G}^{18}$ & $1 \mathrm{M}$ & B & PGV \\
\hline
\end{tabular}

continued on next page

14 Three other equations for site classes B, D and E.

15 Authors state in text that 'more than 14000 ' values were used but their Table 1 gives $2 \times 6899$.

16 State equations valid to 4.5 .

17 State equations valid up to $200 \mathrm{~km}$

18 Call it 'quadratic mean', which is assumed to be geometric mean 
Table 1: continued

\begin{tabular}{|c|c|c|c|c|c|c|c|c|c|c|c|c|c|c|c|c|}
\hline No. & Reference & Area & $\mathrm{H}$ & $\mathrm{v}$ & $\mathrm{E}$ & $M_{\min }$ & $M_{\max }$ & $\begin{array}{l}M \\
\text { scale }\end{array}$ & $r_{\min }$ & $r_{\text {max }}$ & $r$ scale & s & C & $\mathrm{R}$ & $\mathrm{M}$ & IM \\
\hline 69 & Liu and Tsai (2005) & $\begin{array}{l}\text { Taiwan } \\
\end{array}$ & 7907 & 7907 & 51 & 4.05 & 7.10 & $\begin{array}{l}M_{w} \\
\left(M_{L}\right)\end{array}$ & $5^{*}$ & $300^{*}$ & $r_{\text {hypo }}$ & 1 & M & $2 \mathrm{M}$ & A & PGV \\
\hline 70 & McGarr and Fletcher (2005) & $\begin{array}{l}\text { Central Utah coal-mining ar- } \\
\text { eas }\end{array}$ & 72 & - & 12 & 0.98 & 4.2 & $\begin{array}{l}M_{w} \\
\left(M_{C L}\right)\end{array}$ & $0.5^{*}$ & $10^{*}$ & $r_{\text {hypo }}$ & 2 & $\mathrm{~L}$ & $2 \mathrm{M}$ & M & PGV \\
\hline 71 & Megawati et al (2005) & Sumatran interface & \multicolumn{3}{|c|}{ Simulation approach } & 4.5 & 8.0 & $M_{w}$ & 150 & 1500 & $r_{r u p}$ & 1 & G & 1 & F & PGV \\
\hline 72 & Wald et al (2005) & California & $\mathrm{U}$ & - & $\mathrm{U}$ & $\mathrm{U}$ & $5.3^{*}$ & $M_{w}$ & U & U & $r_{i b}$ & 1 & $\mathrm{~L}$ & $\mathrm{U}$ & A & PGV \\
\hline 73 & \begin{tabular}{|l|l} 
Atkinson and Boore (2006) \\
\end{tabular} & E. N. America & \multicolumn{3}{|c|}{ Simulation approach } & 3.5 & 8.0 & $M_{w}$ & 1 & 1000 & $r_{r u p}$ & 1 & $\mathrm{G}$ & 1 & $\mathrm{~A}$ & $\mathrm{PGV}$ \\
\hline 74 & $\begin{array}{l}\text { Bindi et al (2006) } \\
\end{array}$ & Umbria-Marche & 239 & - & 45 & 4.0 & 5.9 & $M_{L}$ & $1^{*}$ & $100^{*}$ & $\begin{array}{l}r_{\text {epi \& }} \\
r_{\text {hypo }} \\
\end{array}$ & 4 & $\mathrm{~L}$ & $1 \mathrm{M}$ & NS & PGV \\
\hline 75 & Kanno et al (2006) & Japan+some foreign & $\begin{array}{l}3392+377 \\
\text { (shal- } \\
\text { low) \& } \\
8150 \\
\text { (deep) }\end{array}$ & - & $\begin{array}{l}73+10 \\
\& 111\end{array}$ & $\begin{array}{l}5.0^{*} \\
(6.1) \\
\& 5.5^{*}\end{array}$ & $\begin{array}{l}8.2^{*} \\
(7.4) \\
\& 8.0^{*}\end{array}$ & $\begin{array}{l}M_{W} \\
\left(M_{\mathrm{JMA}}\right)\end{array}$ & $\begin{array}{l}1^{*} \\
\left(1.5^{*}\right) \\
\& 30^{*}\end{array}$ & $\begin{array}{l}450^{*} \\
\left(350^{*}\right) \\
\& \\
450^{*}\end{array}$ & $\begin{array}{l}r_{\text {rup }} \\
\left(r_{\text {hypo }}\right. \\
\text { for } \\
\text { some) }\end{array}$ & C & $\mathrm{R}$ & $2 \mathrm{M}$ & $\mathrm{A}$ & PGV \\
\hline 76 & Kempton and Stewart (2006) & Worldwide shallow crustal & 1559 & - & 73 & $5.0^{*}$ & $7.6^{*}$ & $M_{w}$ & $0^{*}$ & $200^{*}$ & $r_{\text {rup }}$ & $\mathrm{C}$ & G & $1 \mathrm{M}$ & $\mathrm{A}$ & RSD \\
\hline 77 & $\begin{array}{l}\text { Pousse et al (2006) } \\
\end{array}$ & Japan & $9390^{19}$ & - & $\mathrm{U}$ & 4.1 & 7.3 & $\left(M_{w}\right)$ & $5^{*}$ & $250^{*}$ & $\begin{array}{l}r_{\text {hypo }} \\
\left(r_{\text {rup }}\right. \\
\text { for } \\
\text { some) }\end{array}$ & 5 & B & $2 \mathrm{M}$ & $\mathrm{A}$ & $\begin{array}{l}\mathrm{AI}, \\
\mathrm{RSD}\end{array}$ \\
\hline 78 & Akkar and Bommer (2007) & Europe \& Middle East & 532 & - & 131 & 5.0 & 7.6 & $M_{w}$ & 0 & 99 & $r_{j b}$ & 3 & G & 1WM & $\begin{array}{l}\text { A (N, } \\
\mathrm{S}, \mathrm{R})\end{array}$ & PGV \\
\hline 79 & $\begin{array}{l}\text { Ghodrati Amiri et al (2007a) \& } \\
\text { Ghodrati Amiri et al (2007b) }\end{array}$ & Alborz and central Iran ${ }^{20}$ & $200^{*}$ & $200^{*}$ & $50^{*}$ & $4.5^{*}$ & $7.3^{*}$ & $\begin{array}{l}M_{s} \\
\left(m_{b}\right)\end{array}$ & $5^{*}$ & $400^{*}$ & $r_{\text {hypo }}$ & 2 & $\mathrm{~L}$ & 1 & A & PGV \\
\hline 80 & Bindi et al (2007) & NW Turkey & 4047 & 4047 & 528 & 0.5 & 5.9 & $M_{L}^{21}$ & $5^{*}$ & $200^{*}$ & $r_{\text {hypo } 22}$ & 2 & $\mathrm{~L}$ & $1 \mathrm{M}$ & $\mathrm{A}$ & PGV \\
\hline 81 & Convertito et al (2007) & Campania, Italy & Mainly sin & nulated w & ome natural & 5 & 7 & $M_{w}$ & 5 & 150 & $\frac{r_{e p i}}{r_{e p}}$ & 1 & G & 1 & $\mathrm{~A}$ & $\overline{\text { PGV }}$ \\
\hline
\end{tabular}

19 Does not need to be multiplied by two.

20 Also develop models for the Zagros region of Iran using about 100 records.

${ }^{21}$ Also derive model using $M_{w}$.

22 Also derive model using $r_{e p i}$. 
Table 1: continued

\begin{tabular}{|c|c|c|c|c|c|c|c|c|c|c|c|c|c|c|c|c|}
\hline No. & Reference & Area & $\mathrm{H}$ & $\mathrm{v}$ & E & $M_{\min }$ & $M_{\max }$ & $\begin{array}{l}M \\
\text { scale }\end{array}$ & $r_{\min }$ & $r_{\max }$ & $r$ scale & s & c & $\mathrm{R}$ & M & IM \\
\hline 82 & $\begin{array}{l}\text { Danciu and Tselentis (2007a) \& } \\
\text { Danciu and Tselentis (2007b) }\end{array}$ & Greece & 335 & - & 151 & 4.5 & 6.9 & $M_{w}$ & $0^{*}$ & 136 & $r_{e p i}$ & 3 & A & $1 \mathrm{M}$ & $\begin{array}{l}\text { A (ST, } \\
\text { N) }\end{array}$ & $\begin{array}{l}\text { PGV, } \\
\text { PGD, } \\
\text { AI }\end{array}$ \\
\hline 83 & Fukushima et al (2007) & Japan & 8615 & - & 158 & 5.0 & 6.8 & $M_{J M A}$ & 18.1 & 448.4 & $r_{\text {rup }}$ & 1 & $\mathrm{R}$ & 1 & $\mathrm{~A}$ & PGV \\
\hline 84 & Megawati (2007) & Hong Kong & \multicolumn{3}{|c|}{ Simulation approach } & 5.3 & 6.8 & $M_{w}$ & $20^{*}$ & $60^{*}$ & $r_{\text {rup }}$ & 1 & G & 1 & $\mathrm{~A}$ & PGV \\
\hline 85 & Atkinson (2008) & E. N. America & \multicolumn{3}{|c|}{ Referenced-empirical approach } & 4.3 & 7.6 & $M_{w}$ & $10^{*}$ & $1000^{*}$ & $r_{j b}$ & c & 150 & o & $\begin{array}{l}\mathrm{A}(\mathrm{N}, \\
\mathrm{R}, \mathrm{S}, \\
\mathrm{U})\end{array}$ & PGV \\
\hline 86 & Al-Qaryouti (2008) & Dead Sea area & 26 & - & 19 & 4.0 & 6.2 & $M_{L}$ & 5.8 & 330.6 & $r_{e p i}$ & 1 & $\mathrm{U}$ & 2 & $\mathrm{~A}$ & PGV \\
\hline 87 & $\begin{array}{l}\text { Abrahamson and Silva (2008) \& } \\
\text { Abrahamson and Silva (2009) }\end{array}$ & Worldwide shallow crustal & 2754 & - & 135 & $4.27^{23}$ & $7.9^{24}$ & $M_{w}$ & $0.06^{*}$ & $200^{*}$ & rrup & c & 150 & $1 \mathrm{M}$ & $\begin{array}{l}\mathrm{A}(\mathrm{N}, \\
\mathrm{R}, \mathrm{S}, \\
\mathrm{HW})\end{array}$ & PGV \\
\hline 88 & $\begin{array}{l}\text { Boore and Atkinson (2007) \& } \\
\text { Boore and Atkinson (2008) }\end{array}$ & Worldwide shallow crustal & 1574 & - & 58 & 4.2725 & $7.90^{26}$ & $M_{w}$ & 0 & $280^{27}$ & $r_{j b}$ & c & 150 & $2 \mathrm{M}$ & $\begin{array}{l}\mathrm{A}(\mathrm{N}, \\
\mathrm{R}, \mathrm{S}, \\
\mathrm{U})\end{array}$ & PGV \\
\hline 89 & $\begin{array}{l}\text { Campbell and Bozorgnia (2007), } \\
\text { Campbell and Bozorgnia(2008b) \& } \\
\text { Campbell and Bozorgnia (2008a) }\end{array}$ & Worldwide shallow crustal & 1561 & & 64 & 4.2728 & $7.90^{29}$ & $M_{w}$ & 0.07 & 199.27 & $r_{\text {rup }}$ & c & 150 & $1 \mathrm{M}$ & $\begin{array}{l}\text { A }(\mathrm{N}, \\
\mathrm{R}, \mathrm{S}, \\
\mathrm{HW})\end{array}$ & $\begin{array}{l}\text { PGV, } \\
\text { PGD }\end{array}$ \\
\hline
\end{tabular}

continued on next page

23 Recommend that model is not extrapolated below 5 due to lack of data

24 Believe that model can be reliably extrapolated to 8.5 .

25 Recommend that model is not extrapolated below 5 due to lack of data

${ }^{26}$ Believe that model can be used to 8.0.

27 Recommend that model is not used for distances $\geq 200 \mathrm{~km}$.

${ }^{28}$ Believe that model can be extrapolated down to 4.0 .

29 Believe that model can be extrapolated up to 8.5 for strike-slip faulting and 8.0 for reverse faulting. 
Table 1: contipued

\begin{tabular}{|c|c|c|c|c|c|c|c|c|c|c|c|c|c|c|c|c|}
\hline No. & Reference & Area & $\mathrm{H}$ & $\mathrm{v}$ & E & $M_{\min }$ & $M_{\max }$ & $\begin{array}{l}M \\
\text { scale }\end{array}$ & $r_{\min }$ & $r_{\max }$ & $r$ scale & $\mathrm{s}$ & C & $\mathrm{R}$ & M & $\mathrm{IM}$ \\
\hline 90 & Chiou and Youngs (2008) & Worldwide shallow crustal & 1950 & - & 125 & $4.265^{30}$ & $7.90^{31}$ & $M_{w}$ & $0.2^{* 32}$ & $70^{* 33}$ & rrup & C & 150 & $1 \mathrm{M}$ & $\begin{array}{l}\mathrm{A}(\mathrm{N}, \\
\mathrm{R}, \quad \mathrm{S}, \\
\mathrm{HW}, \\
\mathrm{AS})\end{array}$ & PGV \\
\hline 91 & Jin et al (2008) & Fujian (China) & 1974 & 1974 & 94 & 2.8 & 4.9 & $M_{L}$ & 13 & 462 & $r_{e p i}$ & 1 & $\mathrm{U}$ & $\mathrm{O}$ & A & PGV \\
\hline 92 & Liang et al (2008) & SW W. Australia & & ulation app & & 4.0 & 7.0 & $M_{L}$ & 10 & 200 & $r_{e p i}$ & 1 & G & 1 & $\mathrm{~A}$ & PGV \\
\hline 93 & Massa et al (2008) & $\begin{array}{l}\text { Northern Italy } \\
\end{array}$ & 306 & 306 & 82 & $\begin{array}{l}3.5 \& \\
4.0\end{array}$ & $\begin{array}{l}6.3 \& \\
6.5\end{array}$ & $\begin{array}{l}M_{w} \\
\left(M_{L}\right) \\
\& M_{1}\end{array}$ & $1^{*}$ & $100^{*}$ & $r_{e p i}$ & 3 & $\mathrm{~L}$ & $1 \mathrm{M}$ & A & 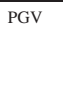 \\
\hline 94 & Mezcua et al (2008) & Spain & 250 & - & 149 & 3.1 & 5.3 & $\begin{array}{l}M_{w} \\
\left(m_{b}\left(L_{g}\right)\right)\end{array}$ & $5^{*}$ & $100^{*}$ & $r_{\text {hypo }}$ & 1 & $\mathrm{u}$ & 1 & A & PGV \\
\hline 95 & $\begin{array}{l}\text { Snzbjörnsson and Sigbjörnsson } \\
\text { (2008) }\end{array}$ & Europe \& Middle East & 71 & - & 13 & $5.0^{*}$ & $7.6^{*}$ & $M_{w}$ & $0^{*}$ & $100^{*}$ & $r_{j b}$ & 1 & $\mathrm{U}$ & 1 & ss & RSD \\
\hline 96 & $\begin{array}{l}\text { Bindi et al (2009a) } \\
\end{array}$ & Italy & 241 & 241 & 27 & 4.8 & 6.9 & $\overline{M_{w}}$ & 0 & 190 & $\begin{array}{l}r_{j b} \\
\left(r_{e p i}\right. \\
\text { for } \\
\text { small })\end{array}$ & 3 & $\mathrm{~L}, \mathrm{G}$ & $1 \mathrm{M}$ & $\begin{array}{l}\text { A (N, } \\
S, R)\end{array}$ & $\begin{array}{l}\mathrm{PGV} \\
\mathrm{PG}\end{array}$ \\
\hline 97 & Bindi et al (2009b) & Italy & 235 & - & 27 & 4.6 & 6.9 & $\begin{array}{l}M_{w} \\
\left(M_{L}\right)\end{array}$ & 0 & 183 & $\begin{array}{l}r_{j b}, \\
r_{e p i}\end{array}$ & 3 & $\mathrm{~L}$ & $1 \mathrm{M}$ & A & PGV \\
\hline 98 & Bommer et al (2009) & Worldwide shallow crustal & 2406 & - & 114 & 4.8 & 7.9 & $M_{w}$ & $1.5^{*}$ & $100^{*}$ & $r_{\text {rup }}$ & $\mathrm{C}$ & B & $\mathrm{o}$ & $\mathrm{A}$ & RSD \\
\hline 99 & Lee (2009) & W. USA ${ }^{34}$ & 324 & 324 & 49 & 5.0 & 7.6 & $\overline{M_{w}}$ & 0.1 & 199.1 & rrup & 2 & $\mathrm{~A}$ & $1 \mathrm{M}$ & $\mathrm{A}$ & $\begin{array}{l}\mathrm{AI} \times 2, \\
\mathrm{RSD} \times 2\end{array}$ \\
\hline 100 & Stafford et al (2009) & New Zealand + foreign & $\begin{array}{l}144+241 \\
\& \\
144+200\end{array}$ & & $23+41$ & 5.08 & 7.51 & $M_{w}$ & 0.07 & 300 & $\begin{array}{l}r_{j b} \& \\
r_{\text {rup }}\end{array}$ & 3 & $\begin{array}{l}\text { L, O, } \\
\text { G, A }\end{array}$ & $1 \mathrm{M}$ & $\begin{array}{l}\mathrm{A} \\
\text { (S/N, } \\
\mathrm{R})\end{array}$ & $\mathrm{AI} \times 4$ \\
\hline
\end{tabular}

continued on next page

30 Believe that model can be extrapolated down to 4.0

${ }^{31}$ Believe that model can be extrapolated up to 8.5 for strike-slip faulting and 8.0 for reverse faulting.

32 Believe that model valid to $0 \mathrm{~km}$.

${ }^{33}$ Believe that model valid to $200 \mathrm{~km}$.

34 Also model for Central USA using 14 records and 296 scaled records 
Table 1: continued

\begin{tabular}{|c|c|c|c|c|c|c|c|c|c|c|c|c|c|c|c|c|}
\hline №. & Reference & Area & $\mathrm{H}$ & $\mathrm{v}$ & E & $M_{\min }$ & $M_{\max }$ & $\begin{array}{l}M \\
\text { scale }\end{array}$ & $r_{\min }$ & $r_{\max }$ & $r$ scale & s & c & $\mathrm{R}$ & M & IM \\
\hline 101 & Akkar and Bommer (2010) & Europe \& Middle East & 532 & - & 131 & 5.0 & 7.6 & $M_{w}$ & 0 & 99 & $r_{j b}$ & 3 & G & $1 \mathrm{M}$ & $\begin{array}{l}\mathrm{A}(\mathrm{N}, \\
\mathrm{S}, \mathrm{R})\end{array}$ & PGV \\
\hline 102 & Akkar and Çağnan (2010) & Turkey & 433 & - & 137 & 5.0 & 7.6 & $M_{w}$ & $0^{*}$ & $200^{*}$ & $r_{j b}$ & c & G & $1 \mathrm{M}$ & $\begin{array}{l}\text { A }(N, \\
S, R)\end{array}$ & PGV \\
\hline 103 & Ghodrati Amiri et al (2010) & Alborz and central Iran ${ }^{35}$ & 416 & - & 189 & $3.2^{36}$ & 7.7 & $\begin{array}{l}M_{s} \\
\left(m_{b}\right)\end{array}$ & $5^{*}$ & $400^{*}$ & $r_{\text {hypo }}$ & 2 & $\mathrm{~L}$ & $1 \mathrm{M}$ & A & AI \\
\hline 104 & Bindi et al (2010) & $\begin{array}{l}\text { Italy } \\
\end{array}$ & 561 & 561 & 107 & 4.0 & 6.9 & $M_{w}$ & $1^{*}$ & $100^{*}$ & $\begin{array}{l}r_{j b}, \\
r_{e p i}\end{array}$ & 3 & $\mathrm{~L}$ & $1 \mathrm{M}$ & A & PGV \\
\hline 105 & Chiou et al $(2010)^{37}$ & $S \& N$ California & 15684 & - & $\mathrm{U}$ & $3^{*}$ & $6^{*}$ & $M_{w}$ & $5^{*}$ & $200^{*}$ & $r_{\text {rup }}$ & C & 150 & $1 \mathrm{M}$ & $\begin{array}{l}\mathrm{A}(\mathrm{N}, \\
\mathrm{R}, \quad \mathrm{S}, \\
\mathrm{HW}, \\
\mathrm{AS})\end{array}$ & $\begin{array}{l}\mathrm{PGV} \\
\times 2\end{array}$ \\
\hline 106 & Iervolino et al (2010) & Italy & 95 & $\cdot$ & 17 & 4.6 & 6.8 & $\begin{array}{l}M_{S} \text { if } \\
M_{L} \& \\
M_{S} \geq \\
5.5 \\
\text { else } \\
M_{L} \\
\end{array}$ & $\begin{array}{l}1.5, \\
1.5\end{array}$ & $\begin{array}{l}179 \\
180\end{array}$ & $\begin{array}{l}r_{j b} \& \\
r_{e p i}\end{array}$ & 3 & $\mathrm{~L}$ & 1 & A & $\begin{array}{l}\mathrm{PGV}, \\
\mathrm{AI}\end{array}$ \\
\hline 107 & Megawati and Pan (2010) & Sumatran interface & & Simulation & & 5 & 9 & $M_{w}$ & $300^{*}$ & $1200^{*}$ & $r_{E}$ & 1 & $\mathrm{G}$ & 1 & $\mathrm{~F}$ & PGV \\
\hline 108 & Rajabi et al (2010) & Zagros, Iran & 37 & - & 35 & 4.1 & 7.0 & $M_{w}$ & 5 & 150 & $r_{e p i}$ & $\begin{array}{l}1,3 \& \\
4\end{array}$ & $\mathrm{~L}$ & 1 & A & $\mathrm{AI} \times 5$ \\
\hline 109 & $\begin{array}{l}\text { Atkinson (2008) modified by } \\
\text { Atkinson and Boore (2011) }\end{array}$ & E. N. America & & enced-emp & approach & 4.3 & 7.6 & $M_{w}$ & $10^{*}$ & $1000^{*}$ & $r_{j b}$ & C & 150 & $\mathrm{o}$ & $\begin{array}{l}\mathrm{A}(\mathrm{N}, \\
\mathrm{R}, \mathrm{S}, \\
\mathrm{U})\end{array}$ & PGV \\
\hline 110 & $\begin{array}{l}\text { Atkinson and Boore (2006) modi- } \\
\text { fied by Atkinson and Boore (2011) }\end{array}$ & E. N. America & & Simulation & & 3.5 & 8.0 & $M_{w}$ & 1 & 1000 & $r_{\text {rup }}$ & 1 & G & 1 & A & PGV \\
\hline
\end{tabular}

35 Also develop models for the Zagros region of Iran using 309 records from 190 earthquakes

${ }^{36}$ State that only use data with $M_{s} \geq 4$ but one earthquake in their Appendix A has $M_{s} 3.2$.

37 Adjustment of GMPE of Chiou and Youngs (2008) for $M_{w}<6$ 
Table 1: continued

\begin{tabular}{|c|c|c|c|c|c|c|c|c|c|c|c|c|c|c|c|c|}
\hline No. & Reference & Area & $\mathrm{H}$ & $\mathrm{v}$ & E & $M_{\min }$ & $M_{\max }$ & $\begin{array}{l}M \\
\text { scale }\end{array}$ & $r_{\min }$ & $r_{\max }$ & $r$ scale & $\mathrm{s}$ & c & $\mathrm{R}$ & M & $\mathrm{IM}$ \\
\hline 111 & $\begin{array}{l}\text { Boore and Atkinson (2007) \& } \\
\text { Boore and Atkinson (2008) modi- } \\
\text { fied by Atkinson and Boore (2011) }\end{array}$ & Worldwide shallow crustal & 1574 & - & 58 & 4.27 & $7.90^{38}$ & $M_{w}$ & 0 & $280^{39}$ & $r_{j b}$ & c & 150 & $2 \mathrm{M}$ & $\begin{array}{l}\text { A }(\mathrm{N}, \\
\mathrm{R}, \mathrm{S}, \\
\text { U) }\end{array}$ & PGV \\
\hline 112 & Alavi et al (2011) & Worldwide shallow crustal & 2252 & - & $\mathrm{U}$ & $5.1^{*}$ & $7.9^{*}$ & $M_{w}$ & $0.2^{*}$ & $350^{*}$ & $r_{\text {rup }}$ & C & $\mathrm{U}$ & 0 & $\begin{array}{l}\text { A } \\
\text { (Rake) }\end{array}$ & $\begin{array}{l}\text { PGV, } \\
\text { PGD }\end{array}$ \\
\hline 113 & Emolo et al (2011) & Campania-Lucania, Italy & 875 & - & 123 & 1.5 & 3.2 & $M_{L}$ & 3 & $100^{*}$ & $r_{h y p o}$ & 2 & L & 1 & A & PGV \\
\hline 114 & $\begin{array}{ll}\text { Ghanat (2011) } \\
\end{array}$ & Worldwide shallow crustal & 2690 & - & 129 & 4.8 & 7.9 & $M_{w}$ & $0.2^{*}$ & $200^{*}$ & $r_{\text {rup }}$ & $\mathrm{C}$ & G & $1 \mathrm{M}$ & $\mathrm{A}$ & RSD \\
\hline 115 & Rupakhety et al (2011) & Worldwide shallow crustal & 93 & - & 29 & 5.56 & 7.6 & $M_{w}$ & 0 & 74.16 & $r_{j b}$ & 1 & $\mathrm{~N}$ & $1 \mathrm{M}$ & $\mathrm{A}$ & PGV \\
\hline 116 & Foulser-Piggott and Stafford (2012) & Worldwide shallow crustal & 2406 & - & 114 & 4.79 & 7.9 & $M_{w}$ & 0.07 & 100 & $r_{\text {rup }}$ & C & A & $1 \mathrm{M}$ & $\begin{array}{l}A \\
(S / N, \\
R)\end{array}$ & AI \\
\hline 117 & Lee et al (2012) & Taiwan & 6570 & - & 62 & 3.93 & 7.62 & $M_{w}$ & 0.3 & 205 & $r_{\text {rup }}$ & C & A & $1 \mathrm{M}$ & $\begin{array}{l}\mathrm{A}(\mathrm{S}, \\
\mathrm{N}, \mathrm{R})\end{array}$ & AI \\
\hline 118 & Nguyen et al (2012) & Vietnam & 330 & - & 53 & 1.6 & 4.6 & $M_{L}$ & $5^{*}$ & $500^{*}$ & $r_{e p i}$ & 1 & L3 & 1 & $\mathrm{~A}$ & PGV \\
\hline 119 & Yaghmaei-Sabegh et al (2012) & Iran & 286 & & 141 & 3.7 & 7.7 & $M_{w}$ & 0.6 & 294 & rrup & 4 & G & 1 & $\mathrm{~A}$ & RSD \\
\hline
\end{tabular}

${ }^{38}$ Believe that model can be used to 8.0

${ }^{39}$ Recommend that model is not used for distances $\geq 200 \mathrm{~km}$. 
List of Figures

1 Predicted PGV at a NEHRP C site against publication date for 96 models published in the literature. Filled red circles indicate models published in peer-reviewed journals, for which basic information on the used dataset is available and which are not being extrapolated far outside their range of applicability. Numbers correspond to those given in Table 1. Also shown is the median PGV within five-year intervals (black line) and the median \pm 1 standard deviation (dashed black lines) based on averaging predictions. Finally indicated is the median PGV (solid blue line) and its 16th and 84th confidence limits (dashed blue line) based on averaging records up until that date (see text for details). Note that the selection criteria and the fact that the database used to compute these averages has not been recently updated mean that the blue lines end before $2012 \ldots \ldots \ldots$

2 Like Figure 1 but for PGD (19 models). . . . . . . . . . . . . . . . . . . 39

3 Like Figure 1 but for AI (33 models). . . . . . . . . . . . . . . . . . 40

4 Like Figure 1 but for RSD (14 models). . . . . . . . . . . . . . . . . 41 


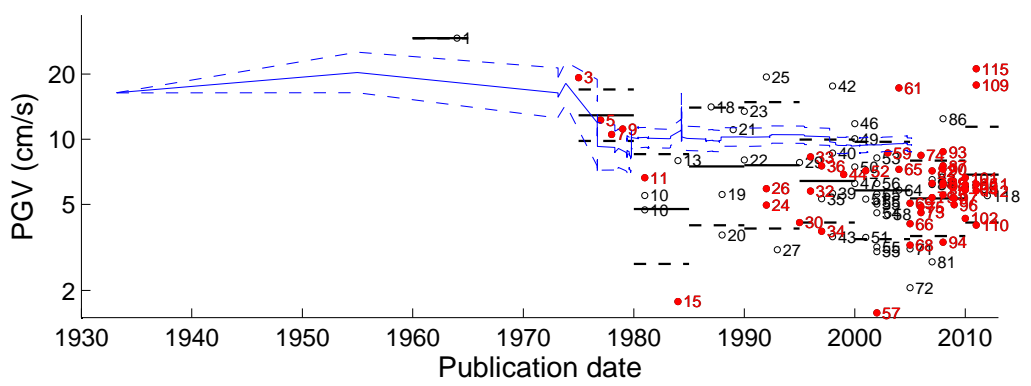

(a) For a $M_{w} 6$ strike-slip earthquake at $r_{j b}=20 \mathrm{~km}$. Up until the end of 2005, 253 records from 56 earthquakes were used to compute the average observed PGV.

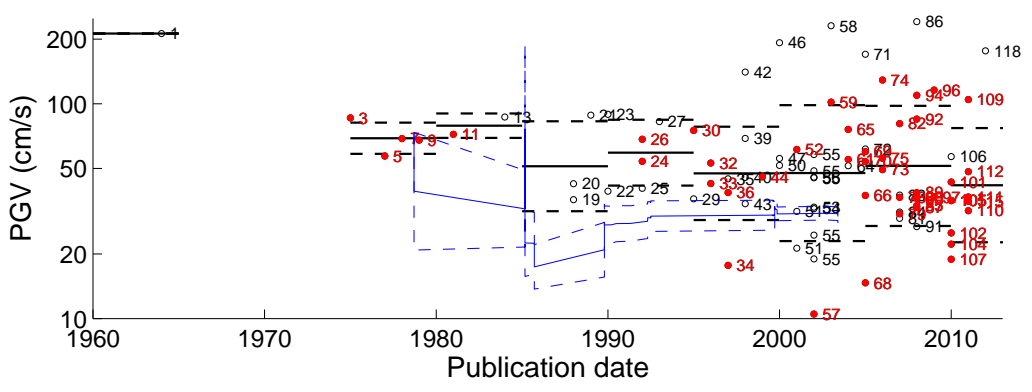

(b) For a $M_{w} 7.5$ strike-slip earthquake at $r_{j b}=10 \mathrm{~km}$. Up until the end of 2003, 129 records from 15 earthquakes were used to compute the average observed PGV. The vertical blue line in 1985 is caused by many number of records from the same date (the Chile earthquake of 3rd March 1985) that significantly change the average computed up to that time.

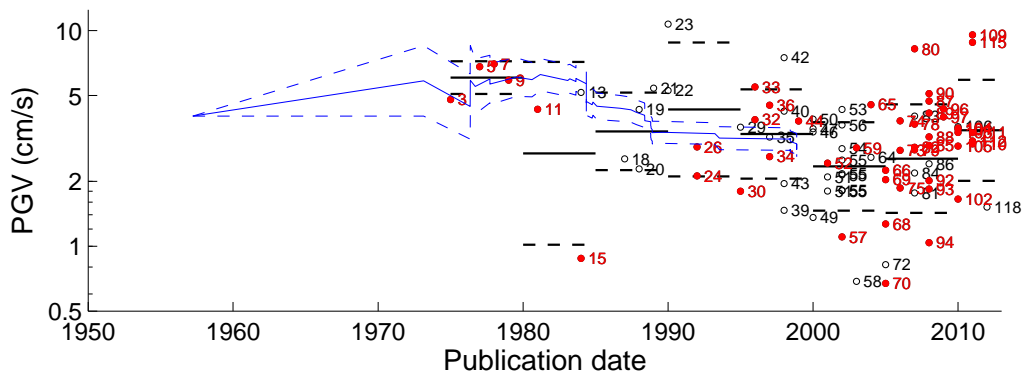

(c) For a $M_{w} 5$ strike-slip earthquake at $r_{j b}=10 \mathrm{~km}$. Up until the end of 1998,51 records from 30 earthquakes were used to compute the average observed PGV.

Fig. 1 Predicted PGV at a NEHRP C site against publication date for 96 models published in the literature. Filled red circles indicate models published in peer-reviewed journals, for which basic information on the used dataset is available and which are not being extrapolated far outside their range of applicability. Numbers correspond to those given in Table 1. Also shown is the median PGV within five-year intervals (black line) and the median \pm 1 standard deviation (dashed black lines) based on averaging predictions. Finally indicated is the median PGV (solid blue line) and its 16th and 84th confidence limits (dashed blue line) based on averaging records up until that date (see text for details). Note that the selection criteria and the fact that the database used to compute these averages has not been recently updated mean that the blue lines end before 2012. 


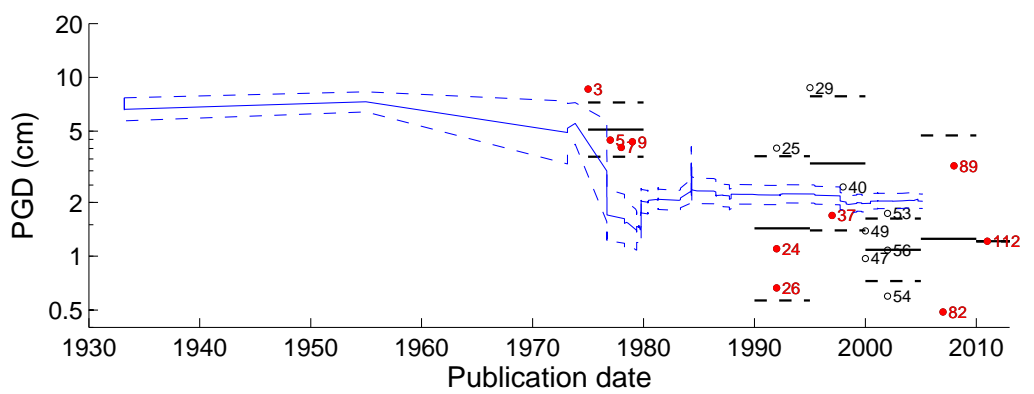

(a) For a $M_{w} 6$ strike-slip earthquake at $r_{j b}=20 \mathrm{~km}$.

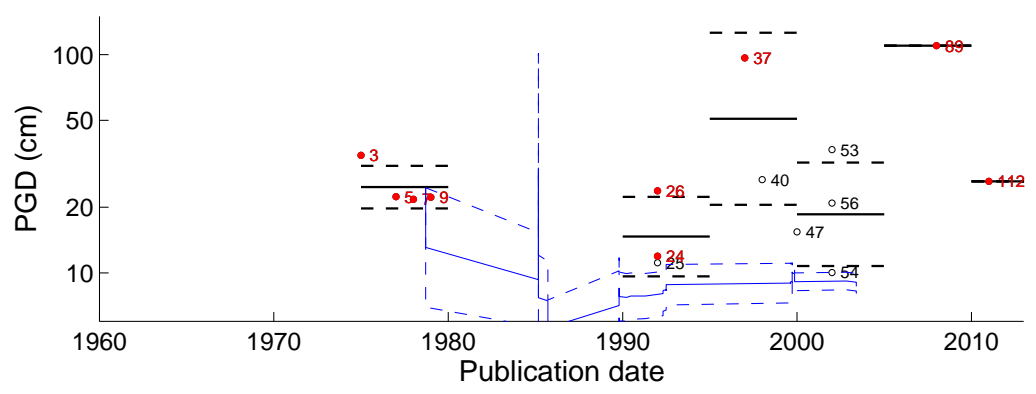

(b) For a $M_{w} 7.5$ strike-slip earthquake at $r_{j b}=10 \mathrm{~km}$.

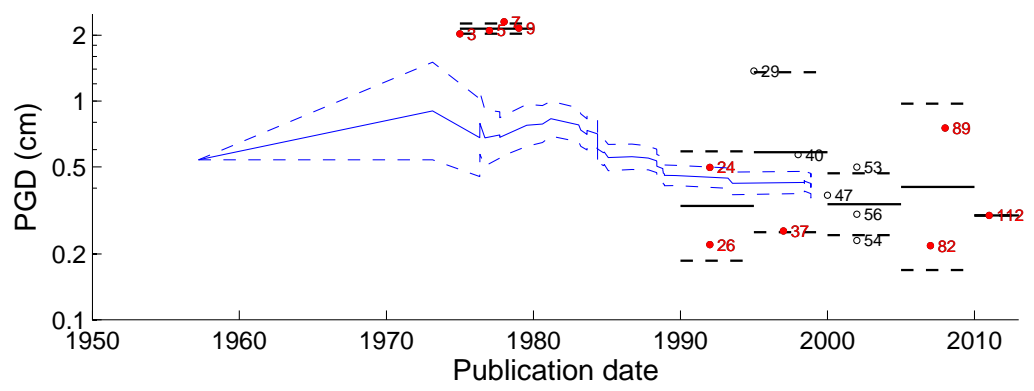

(c) For a $M_{w} 5$ strike-slip earthquake at $r_{j b}=10 \mathrm{~km}$.

Fig. 2 Like Figure 1 but for PGD (19 models). 


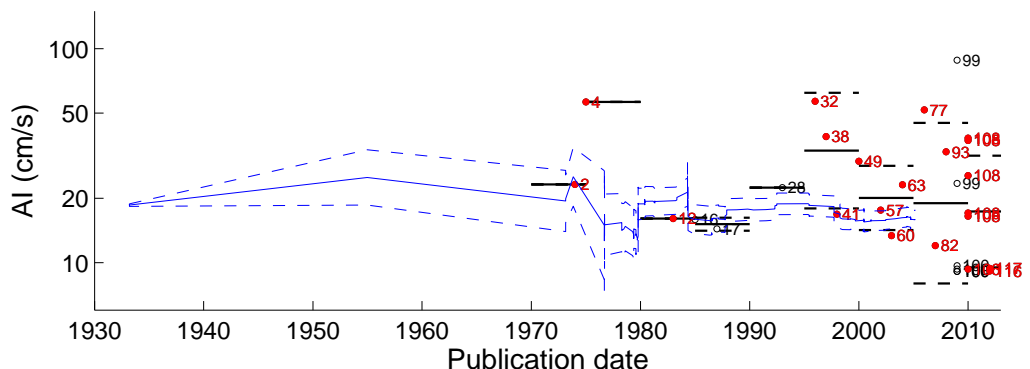

(a) For a $M_{w} 6$ strike-slip earthquake at $r_{j b}=20 \mathrm{~km}$.

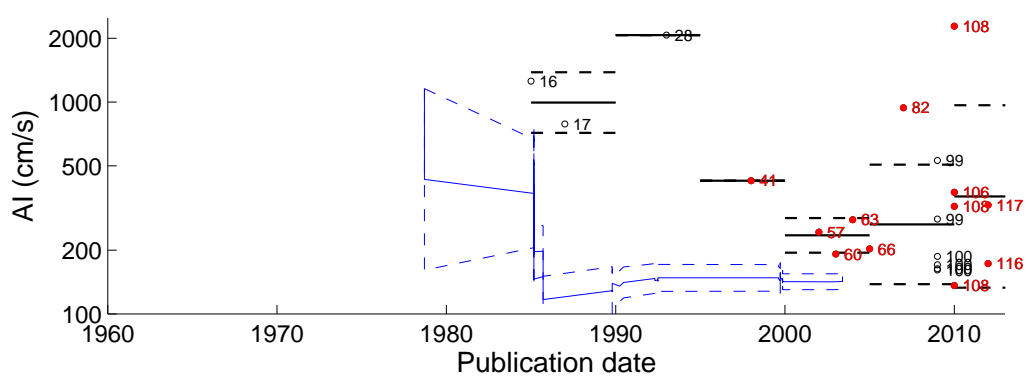

(b) For a $M_{w} 7.5$ strike-slip earthquake at $r_{j b}=10 \mathrm{~km}$.

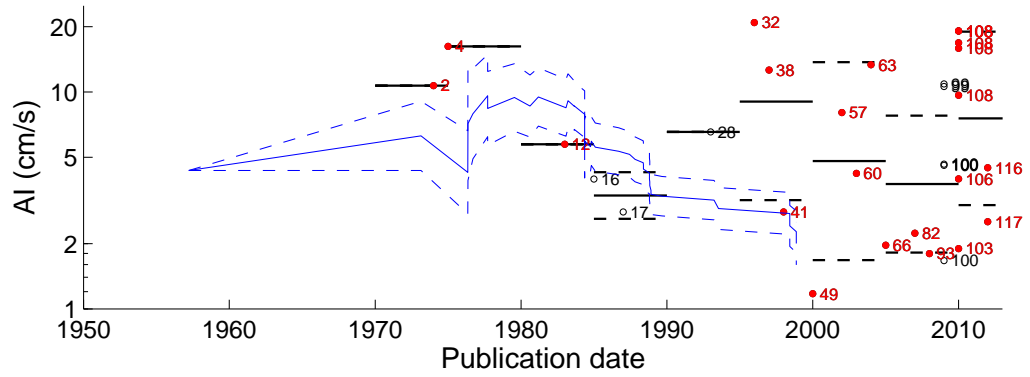

(c) For a $M_{w} 5$ strike-slip earthquake at $r_{j b}=10 \mathrm{~km}$.

Fig. 3 Like Figure 1 but for AI (33 models). 


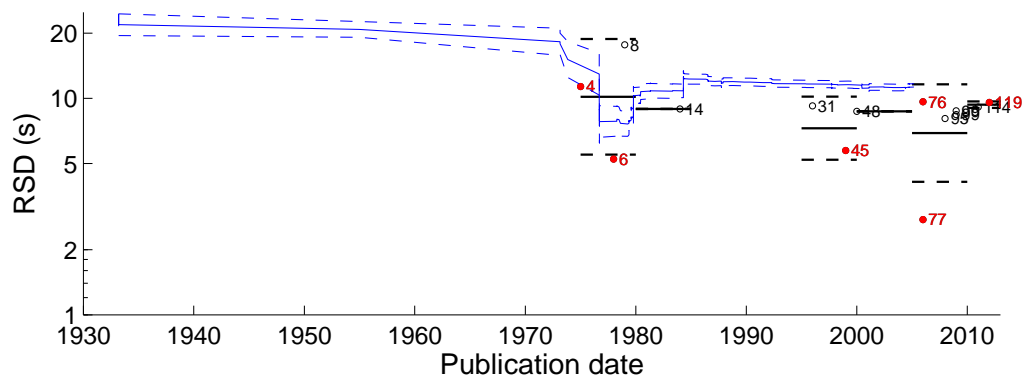

(a) For a $M_{w} 6$ strike-slip earthquake at $r_{j b}=20 \mathrm{~km}$.

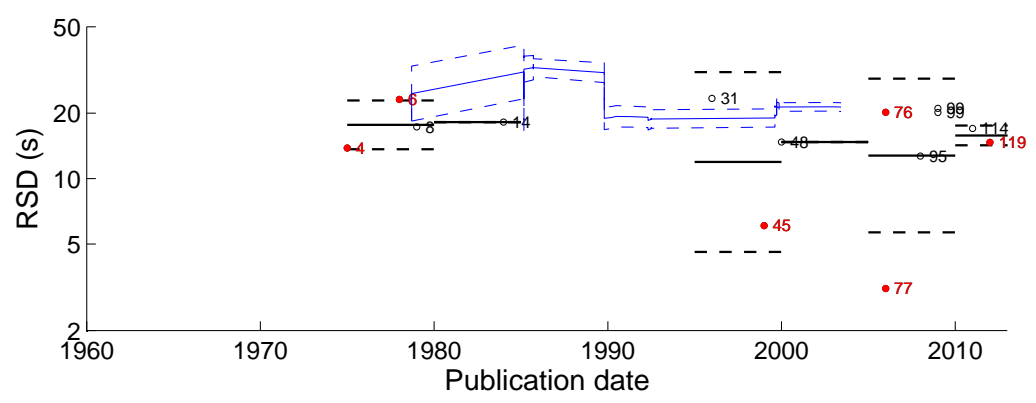

(b) For a $M_{w} 7.5$ strike-slip earthquake at $r_{j b}=10 \mathrm{~km}$.

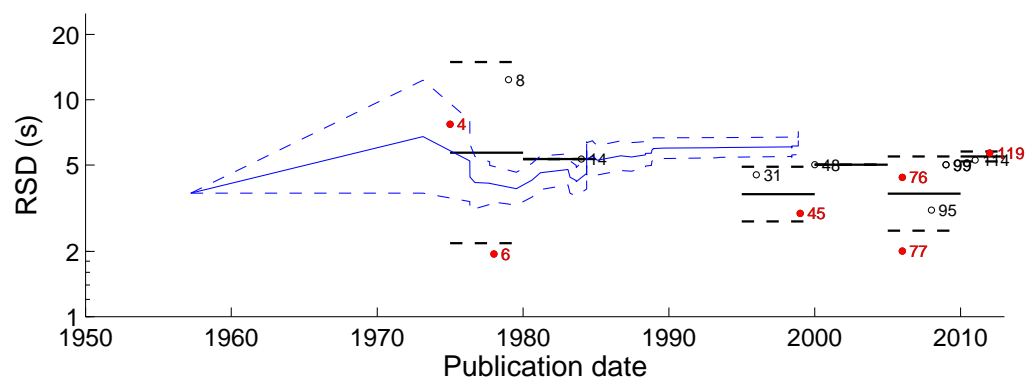

(c) For a $M_{w} 5$ strike-slip earthquake at $r_{j b}=10 \mathrm{~km}$.

Fig. 4 Like Figure 1 but for RSD (14 models). 